NBER WORKING PAPER SERIES

\title{
AN ASSESSMENT OF THE PROPOSALS OF THE PRESIDENT'S COMMISSION TO STRENGTHEN SOCIAL SECURITY
}

\author{
Peter A. Diamond \\ Peter R. Orszag \\ Working Paper 9097 \\ http://www.nber.org/papers/w9097
NATIONAL BUREAU OF ECONOMIC RESEARCH
1050 Massachusetts Avenue
Cambridge, MA 02138

August 2002

The views expressed herein are those of the authors and not necessarily those of the National Bureau of Economic Research.

(C) 2002 by Peter A. Diamond and Peter R. Orszag. All rights reserved. Short sections of text, not to exceed two paragraphs, may be quoted without explicit permission provided that full credit, including (C) notice, is given to the source. 
An Assessment of the Proposals of the President's Commission to Strengthen Social Security

Peter A. Diamond and Peter R. Orszag

NBER Working Paper No. 9097

August 2002

\begin{abstract}
$\underline{\text { ABSTRACT }}$
The President's Commission to Strengthen Social Security proposed three reform plans. Two, analyzed here, restore actuarial balance in the absence of individual accounts. One achieves this balance solely through benefit reductions. The other uses new dedicated revenue to cover one-third of the actuarial deficit, reducing benefits to close the rest. Both plans cut disability and young survivor benefits in step with retirement benefits, while bolstering benefits for long-career low earners and surviving spouses with low benefits.

The plans both include voluntary individual accounts that replace part of the scaled-back Social Security system. Payroll taxes are diverted to the accounts and one of the plans also requires a (subsidized) add-on contribution for those choosing accounts. Under both models, any payroll tax deposited in an individual account is also recorded in a "liability account" for the worker. The liability account tracks the diverted payroll revenue (with interest) and is paid off by reducing traditional benefits. The individual accounts are subsidized through a sub-market interest rate on the liability accounts. This subsidy worsens the financial position of the Trust Fund. The accounts also create a cash-flow problem. Consequently, by themselves, the individual accounts make Social Security's solvency problems worse both in the short run and over the long run.

To offset the adverse impact of the accounts, the plans call for large transfers of general revenues (despite substantial projected budget deficits). If all (two-thirds of) eligible workers opted for the accounts, the new revenues required over the next 75 years would amount to between 1.2 and $1.5(0.8$ and 1.1) percent of payroll. Holding the disabled harmless from the benefit reductions would raise the required transfers to between 1.5 and 1.7 (1.1 and 1.3) percent of payroll (compared to a projected actuarial deficit of 1.9 percent of payroll under current law). Despite requiring this much general revenue relative to paying scheduled benefits, the plans would produce significant reductions in expected combined benefits. At the end of 75 years, however, assets in the accounts would amount to between 53 and 66 (35 and 44) percent of GDP, and the value to Social Security of the accumulated liabilities that reduce later benefits would amount to more than 20 (15) percent of GDP.
\end{abstract}

Peter A. Diamond

Department of Economics

MIT

50 Memorial Drive, E52-344

Cambridge, MA 02142

and NBER

pdiamond@mit.edu
Peter R. Orszag

Economic Studies

The Brookings Institution

1775 Mass. Ave. NW

Washington, DC 20036

porszag@brookings.edu 


\title{
An Assessment of the Proposals of the President's Commission to Strengthen Social Security
}

\author{
Peter A. Diamond and Peter R. Orszag ${ }^{1}$ \\ July, 2002
}

Social Security is running short-term surpluses but faces a long-term actuarial imbalance. According to the intermediate cost projections contained in the 2002 Annual Report of the Social Security Trustees, the projected imbalance over the next 75 years amounts to 1.87 percent of taxable payroll. ${ }^{2}$ In other words, an increase in the payroll tax rate of 1.87 percentage points (.935 each for employer and employee) starting in 2003 would be needed to balance projected revenues and outlays over the 75-year horizon traditionally used to examine the financial position of Social Security. Moreover, the Trustees' Report projected that the Trust Fund would be exhausted (reach zero) in 2041, at which point incoming revenue would be sufficient to finance only about 75 percent of scheduled benefits. ${ }^{3}$

Social Security's long-term actuarial imbalance, combined with a desire by some to introduce individual accounts into the program, has sparked interest in reform over the past several years. ${ }^{4}$ Indeed, Social Security figured prominently in the 2000 presidential campaign. Following the election, President Bush appointed a commission -- the President's Commission to Strengthen Social Security -- with two charges and several constraints. One was to find a way to

\footnotetext{
${ }^{1}$ We thank Greg Anrig, Barry Bosworth, Robert Cumby, William Gale, Stephen Goss, Robert Greenstein, Kilolo Kijakazi, Alicia Munnell, Richard Leone, Jeffrey Liebman, Michael Orszag, Jim Poterba, Wendell Primus, and Bernard Wasow for helpful comments and/or discussions. The views expressed here are those of the authors alone and do not necessarily represent those of the staff, trustees, or officers of the institutions with which the authors are affiliated. For a less technical version of our analysis, see Peter Diamond and Peter Orszag, "Reducing Benefits and Subsidizing Individual Accounts: An Analysis of the Plans Proposed by the President's Commission to Strengthen Social Security," The Century Foundation and the Center on Budget and Policy Priorities, June 18, 2002.

${ }^{2}$ See 2002 Annual Report of the Board of Trustees of the Federal Old-Age and Survivors Insurance and Disability Insurance Trust Funds. The actuarial imbalance figure reflects the intermediate cost projections and includes the cost of ensuring that the Trust Fund at the end of the evaluation period is equal to one year's expenditures. The imbalance amounts to 0.7 percent of GDP over the next 75 years.

${ }^{3}$ The evaluation by the Office of the Chief Actuary at Social Security of the Commission's proposals were based on the intermediate cost assumptions used in the 2001 report rather than the 2002 report. The 2001 assumptions produced a 75-year actuarial imbalance of 1.86 percent of payroll and a projected date of Trust Fund exhaustion of 2038.
} 
restore "financial soundness" to the system. The second was to design a system of voluntary individual accounts. (Box 1 provides the precise wording of the charge to the Commission.) After deliberating for approximately eight months, the Commission issued a final report in December 2001 that contained three different proposals. ${ }^{5}$

One of the three Commission proposals (Model 1) would not restore long-term balance to Social Security and is therefore not considered in much detail here. The other two models substantially reduce traditional Social Security benefits in order to improve the system's longterm balance. Indeed, these two models achieve actuarial balance in the absence of their individual account proposals. The models also create individual accounts that replace part of the scaled-back Social Security system. By themselves, the accounts worsen Social Security's longterm actuarial balance because of subsidies provided to workers opting for the accounts. The accounts also create a cash-flow problem since revenues are diverted away from Social Security decades before benefits are reduced as a result of the accounts.

To deal with the deterioration in Social Security's finances generated by the individual accounts, Models 2 and 3 call for significant infusions of general revenue into Social Security. Given the dramatic deterioration in the nation's fiscal outlook, however, simply assuming the availability of large transfers, without specifying other changes in the Federal budget to accommodate such transfers, would appear to be problematic.

The purpose of this paper is to describe and assess the proposals included in the Commission's final report. Before turning to the analysis, one issue is worth highlighting: the baseline against which the proposed benefits are compared. In describing both benefit levels and fiscal implications, we initially compare the proposals to "scheduled benefits," which are those given by the current benefit formula without making any adjustment for the current level of actuarial imbalance. This baseline has some advantages. First, the current benefit formula has an inherent economic logic: it maintains replacement rates from one generation to the next for

\footnotetext{
${ }^{4}$ For a history of the reform debate during the 1990s, see Douglas W. Elmendorf, Jeffrey B. Liebman, and David W. Wilcox, "Fiscal Policy and Social Security Policy During the 1990s," in Jeffrey A. Frankel and Peter R. Orszag, eds., American Economic Policy in the 1990s (MIT Press: 2002).
} 
workers with the same earnings relative to the average wage (once the normal retirement age has stabilized). Second, since it is embodied in legislation, the current benefit formula is unambiguous and does not require assumptions about how benefits might be adjusted in the future. The major limitation of using scheduled benefits as the baseline, however, is that Social Security would not be able to pay these scheduled benefits without additional revenue. In particular, paying scheduled benefits would require additional financing equal to 1.87 percent of taxable payroll over the next 75 years. Despite this long-term financing gap, we use scheduled benefits as the baseline in our initial analysis. ${ }^{6}$ We note that this treatment conforms to the approach to evaluating Social Security reforms adopted by the Greenspan Commission in 1983 and the Advisory Council in 1994-1996, both of which used the scheduled benefit formula as the baseline despite projected long-term deficits in Social Security. Importantly, by using a single baseline throughout the initial analysis, we describe not only benefit levels but also fiscal implications relative to the same standard. ${ }^{7}$ This removes the temptation to focus attention on different baselines for different implications of a proposal. ${ }^{8}$

${ }^{5}$ A revised final report was issued in March 2002. All page numbers and references in this document refer to the March 2002 version of the Report.

${ }^{6}$ The Commission used three baselines, scheduled benefits, payable benefits, and real benefits paid to current retirees. "Payable benefits" are defined as the benefits that could be financed by projected revenues under current law, assuming no change in revenues or benefits until the Trust Fund is exhausted, followed by a cut in benefits so that annual benefits equal annual revenues. Two problems arise with regard to this alternative baseline. First, the pattern of benefits is complex, making it harder to follow the implications of the proposals. Second, the payable benefit baseline may be even less plausible politically than the scheduled benefit baseline. As Chairman Greenspan has emphasized, the pattern of no action followed by such sharp benefit cuts embodied in the "payable benefits" baseline simply will not happen. (Alan Greenspan, "Saving for Retirement," Remarks before the 2002 National Summit on Retirement Savings, the Department of Labor, Washington, D.C., February 28, 2002.) The Commission argues against use of the scheduled benefit baseline because "confusion occasionally arises when comparisons are made between two different plans that employ different levels of tax revenue." (President's Commission to Strengthen Social Security, Strengthening Social Security and Creating Personal Wealth for All Americans, page 35.) We recognize that such confusion can arise. We note, however, that the Commission's plans involve substantial amounts of general revenue transfers. The "payable benefits" baseline, on the other hand, involves no general revenue transfers by definition, since Social Security benefits are always maintained at the level of Social Security revenue. The Commission's comparison of the benefits under its plans to the "payable benefits" baseline thus violates its own warning against comparing plans with different levels of assumed tax revenue. Indeed, if one wanted to compare plans to a baseline with the same level of assumed general revenue, Models 2 and 3 would be more appropriately compared to the scheduled benefit baseline than the payable benefit baseline, because the level of general revenue transfers under Models 2 and 3 over the next 75 years are much closer to the level of transfers required to finance scheduled benefits than to zero.

${ }^{7}$ In particular, using scheduled benefits as the baseline for comparing revenue infusions, but payable benefits as the baseline for benefit comparisons, could easily create confusion. For example, Model 2's combined benefits are lower than scheduled benefits, but Model 2's actuarial deficit (absent general revenue transfers) is also lower than with scheduled benefits. At the same time, Model 2's combined benefits are less than payable benefits until the Trust Fund is exhausted and then eventually larger than payable benefits. Since payable benefits, by definition, need no additional revenues, Model 2's actuarial deficit (absent transfers) is higher than with payable benefits. With two baselines, it is therefore possible for advocates of Model 2 to assert that it offers higher benefits (than payable 
Use of scheduled benefits as the initial baseline in this analysis, however, is not meant to imply in any way that reforms to the current system are unnecessary. Indeed, we favor restoring actuarial balance with legislation in the near future that slowly phases in a combination of changes to the Social Security system, including adjustments to both revenues and benefits. It is also important to emphasize that we examine the effects of alternative baselines in a later section of the paper, where we provide information on two alternative baselines that achieve 75-year solvency with the same level of general revenue transfers as Model 2.

To examine the effects of the Commission's proposals, Section I begins with the proposed changes in the determination and financing of traditional Social Security benefits. Examining these changes to traditional benefits is important as a building block in understanding the overall effects of the proposals, and is crucially important in understanding the effects for workers who choose not to contribute to the individual accounts. Section II then examines the structure of the individual accounts proposed by the Commission. Section III presents the combined effects of the individual accounts and the changes to the traditional component of Social Security in terms of assets, cash flows, actuarial imbalance, and monthly benefits for workers with different earnings levels. ${ }^{9}$ Section IV offers some conclusions.

\section{Changes in Scheduled Benefits}

The Commission referred to its three proposals as "reform models." The first contains an individual account plan without any changes to the traditional system, and therefore is not described in this section (since there is nothing to explain about its impact on scheduled

\footnotetext{
benefits) and less demand on general revenues (than scheduled benefits), while an opponent can assert that Model 2 offers lower benefits (than scheduled benefits) and makes a greater demand on general revenues (than payable benefits). Both statements are literally accurate and both have the potential to mislead. Using a single baseline is more transparent and less likely to cause confusion.

${ }^{8}$ To see the role of multiple baselines in the Commission Report, consider the discussion of Model 2 on pages 121 to 129 . When discussing benefits, scheduled benefits are by and large ignored, appearing only in a footnote in the table on page 122. When discussing financing, only scheduled benefits are discussed. Furthermore, the term "current law" is used to refer to payable benefits in the table on benefits on page 122 and to scheduled benefits in the figures on financing on pages 125 and 126.

${ }^{9}$ We do not explore the important issue of the impact of the plans on national saving. For a preliminary analysis of that topic, see Barry Bosworth and Gary Burtless, "Economic and Distributional Effects of the Proposals of President Bush’s Social Security Commission," Center for Retirement Research, May 20, 2002.
} 
benefits). The second and third proposals contain changes to the traditional Social Security system that would restore actuarial balance in the absence of the individual account component.

\section{A. Model 2 Proposals for Traditional Benefits and their Financing}

The future benefit reductions in Model 2 are sufficient to restore actuarial balance to Social Security with no new sources of revenue, while also financing two modest expansions in benefits for needy groups. The plan accomplishes this objective by changing from the current wage-indexed system for determining initial benefits at retirement to one that uses a price index as part of the determination of initial benefits.

Under current law, initial retirement benefits are based on a worker's average indexed monthly earnings (AIME). AIME, in turn, is determined by taking earnings in previous years and scaling them up by subsequent national average wage growth. ${ }^{10}$ The "bend points" of the formula relating full benefits (the so-called Primary Insurance Amount) to earnings are also indexed to average earnings. ${ }^{11}$ Under this approach, the benefit system is designed to maintain a constant replacement rate across generations - that is, the full retirement benefit as a share of pre-retirement earnings is constant over time for successive cohorts of workers with the same earnings relative to average earnings.

A constant replacement rate across generations may seem like an abstract concept, but it serves the crucial purpose of allowing beneficiaries to share in the general increase in the standard-of-living that society as a whole experiences from one generation to the next. A focus on replacement rates also recognizes the psychological phenomenon by which families become accustomed to a given level of consumption; substantial declines in income during retirement can pose difficult adjustment problems.

\footnotetext{
${ }^{10}$ More precisely, the wage indexing occurs through the year in which a worker turns 60 . The initial benefit level is thus indexed to wage growth. After initially claiming benefits, benefit increases are indexed to price growth. Price indexing of benefits begins after the year in which a worker turns 62. Thus there is a gap with no indexing, which should be corrected (and could be corrected on a revenue-neutral basis if desired).
} 
The Commission's proposal would alter the current system so that in determining the initial benefit level, benefits would keep pace with price growth, not wage growth. More precisely, the proposal would multiply the 90 percent, 32 percent and 15 percent factors used to compute the Primary Insurance Amount by the ratio of cumulative price growth to cumulative wage growth between 2008 and the year in which a worker becomes entitled to claim benefits. This approach leads to real benefit levels that are constant over time, rather than increasing in line with real wages. Since real wage growth is positive on average, the change would reduce initial benefit levels and the size of the reduction would increase over time. The latest Trustee's Report projects long-run growth of prices of 3.0 percent per year and long-run growth of taxable wages of 4.1 percent per year. Over 10 years, cumulative price growth is then 90 percent of wage growth; over 20 years, 81 percent; over 40 years, 65 percent. $^{12}$

The implications of the proposed change on benefit levels are dramatic. One of the President's charges to the Commission was to preserve the level of benefits for retirees and for those nearing retirement. The Commission interpreted that charge as applying to workers age 55 and over on January 1, 2002. Under Model 2, the reductions in benefits would therefore be phased in starting with workers who were 54 at the beginning of 2002 . For each additional year that a worker is younger than 55, the benefit formula is projected to be reduced by an additional one percent (approximately - one percent is the assumed ultimate real wage growth for the 2001

\footnotetext{
${ }^{11}$ In 2002, the Primary Insurance Amount is equal to 90 percent of the first $\$ 592$ of AIME; 32 percent of AIME over $\$ 592$ and through $\$ 3,567$; and 15 percent of AIME over $\$ 3,567$. The "bend points" at which the 90, 32, and 15 percent factors apply are indexed to wage growth.

${ }^{12}$ The principle of price indexing was supported by a panel on which Diamond served in 1974-5 (Panel on Social Security Financing consulting to U.S. Senate Finance Committee). At the time, that principle seemed appropriate since the magnitude of the actuarial imbalance was so severe that it was difficult to see how Congress would legislate sufficient benefit reductions and/or revenue increases to restore solvency to the system while retaining wage indexation. The severity of the projected imbalance at that time was underscored by the fact that the subsequent 1977 legislation was followed very shortly after by the 1983 legislation. According to the 1975 Trustees' Report, the actuarial deficit was 5.32 percent of payroll and the Trust Fund was projected to be exhausted in five years. By 1976, the actuarial deficit was up to 7.96 percent, with a slightly later projected exhaustion. By contrast, the actuarial imbalance is now 1.87 percent of payroll and the projected date of trust fund exhaustion is nearly four decades away. Since the financial situation now is far less severe, a dramatic alteration in the system is neither needed nor desired. Furthermore, the type of price indexing adopted by the Commission in Model 2 is more severe than the approach proposed by the 1974-5 panel on which Diamond served. The 1974-5 panel proposed indexing both Average Indexed Monthly Earnings and the bend points to price inflation rather than wage growth; that approach would still allow real benefit increases over time. By contrast, the Commission proposal maintains a constant real benefit level. For further detail on the alternative approaches, see Stephen C. Goss, "Long-Range OASDI Financial Effects of a Proposal to CPI-Index Benefits Across Generations," Office of the Chief Actuary, Social Security Administration, May 3, 1999.
} 
Trustees' intermediate cost projections, with slightly different growth rates in the first ten years of the projection). ${ }^{13}$ With these reductions compounding, the pattern shown in Table 1 emerges. Thus a current 35-year old would have benefits reduced by 17.4 percent under the proposal compared to scheduled benefits under current legislation. The future benefit level for a newborn in 2002 would be reduced by 41.0 percent relative to the scheduled benefit level. ${ }^{14}$

The replacement rates from Social Security would be reduced by corresponding percentages. Under current law, for example, Social Security is scheduled to replace slightly more than 36 percent of former earnings for single workers with average earnings retiring at age 65 in 2025 or thereafter (or equivalently two-earner couples with the same earnings each). ${ }^{15}$ Under Model 2, the replacement rate would fall to 30 percent for a current 35-year-old and to 22 percent for a newborn in 2002. The role of the Social Security system in allowing the elderly to maintain their standard of living after retirement would thus decline sharply over time.

The proposed change in the indexation system is more than sufficient, by itself, to eliminate the 75 -year actuarial imbalance in Social Security. We discuss actuarial balance issues in more detail below.

\section{Disability and Young Survivor Benefits}

The same benefit formula that is used for retirement benefits is also used for disability benefits. Thus the switch to price indexation means that a worker becoming entitled to disability benefits in 2020 would have disability benefits reduced by 10.7 percent; a worker becoming entitled in 2040 would have disability benefits reduced by 26.4 percent; and a worker becoming

\footnotetext{
${ }^{13}$ The Trustees' Report makes year-by-year assumptions for 10 years and then uses an ultimate assumption of 1.0 percent per year real wage growth for the remaining years to the projection horizon. In the 2002 Trustees' Report, the ultimate rate of growth of real wages is taken to be 1.1 percent.

${ }^{14}$ Within the traditional 75-year horizon, the largest reduction in retirement benefits would occur for a worker reaching age 62 in 75 years. Of course, such a worker is not yet alive. For such a future worker, the reduction would be almost 50 percent. The reductions relative to scheduled benefits would be somewhat larger under the 2002 Trustees assumptions, because the assumed real wage growth rate is higher than under the 2001 assumptions. Under the 2002 assumptions, for example, shifting to price indexing would reduce benefits for a newborn in 2002 by 44.1 percent (compared to 41.0 percent under the 2001 assumptions).

${ }_{15}$ The replacement rates at age 65 are higher but declining during the period that the normal retirement age is increasing (i.e., until to 2025).
} 
entitled in 2075 would have disability benefits reduced by 47.5 percent (see Table 2). Yet, many disabled workers would have little opportunity to accumulate substantial balances in their individual accounts to offset these benefit reductions - and in any case, they would not be allowed access to their individual account balances prior to retirement age.

Since, on average, disabled beneficiaries are financially poorly off, the proposed changes represent a large reduction in benefits for a needy group. ${ }^{16}$ Furthermore, minorities, on average, have higher rates of disability than the rest of the population and therefore disproportionately benefit from the disability benefits that Social Security provides. For example, Social Security data show that 1.1 percent of black workers aged 50-59 became disabled in 1997, relative to 0.6 percent of all workers. ${ }^{17}$ Blacks account for 13 percent of working-age Americans, but 17 percent of disabled worker beneficiaries. The reductions in disability benefits would thus disproportionately harm minorities. ${ }^{18}$

The Commission was aware of these issues and stated explicitly that some other group needed to examine disability benefits and that "the calculations carried out for the commission and included in this report assume that defined benefits will be changed in similar ways for the two programs [OASI and DI]. This should not be taken as a Commission recommendation for policy implementation." 19 Nonetheless, the Commission dedicated no revenue to financing a

\footnotetext{
${ }^{16}$ For data on the circumstances of the disabled, see, for example, Virginia Reno, Jerry Mashaw, and Bill Gradison, eds., Disability: Challenges for Social Insurance, Health Care Financing, and Labor Market Policy (National Academy of Social Insurance: 1997).

${ }^{17}$ Office of Policy, Office of Research, Evaluation, and Statistics, Social Security Administration, "Earnings of Black and Nonblack Workers: Who Died or Became Disabled in 1996 and 1997?" Note No. 2000-01, November 2000 .

${ }^{18}$ A final point about disability benefits is worth noting. The reduction in disability benefits relative to scheduled benefits from the shift to price indexation would depend on the worker's year of disability, not the year of entitlement to retirement benefits. Thus a 20 -year-old worker in 2002 who claimed disability benefits at age 40 (in 2022) would experience a reduction in disability benefits of 12 percent relative to scheduled benefit levels - and that real benefit level would continue after the worker reached retirement age. If that worker continued working until retirement, however, the reduction in benefits would amount to 30 percent. Entitlement to disability benefits would effectively lock in a smaller benefit reduction (relative to scheduled benefits) than entitlement to retirement benefits. It is worth noting, however, that the real level of benefits (as opposed to the reduction relative to scheduled benefits) would be the same for the disabled beneficiary and the retired beneficiary.

${ }^{19}$ The Commission Report states: "DI beneficiaries may not have their full adult lives in which to accumulate a retirement account, so this is a rationale for maintaining their traditional benefits. However, if benefits were changed for OASI but not DI, this might lead to an increase in DI applicants. The Commission urges the Congress to consider the full range of options available for addressing these concerns. In the absence of fully developed proposals, the calculations carried out for the commission and included in this report assume that defined benefits will be changed in similar ways for the two programs. This should not be taken as a Commission recommendation
} 
more modest reduction in disability benefits. Instead, it included dramatic benefit cuts for the disabled as part of the solution to restoring actuarial balance. The reductions in disability benefits included in Model 2 improve solvency by roughly 0.3 percent of payroll over the next 75 years. $^{20}$ Without these large savings, Model 2 would not achieve long-term balance.

Similarly, Social Security also provides benefits to the young children of workers who die (as well as the children of workers who become disabled). The reduction in the scheduled benefit formula, described above, has the same proportional impact on benefits for young children as it does on disabled workers. Thus, the benefit for surviving children whose parent died in 2020 would be reduced by 10.7 percent; and the benefit for a surviving child in 2075 would be reduced by 47.5 percent relative to scheduled benefit levels. African-American children would be disproportionately affected by these benefit reductions; they currently constitute 15 percent of Americans under age 18 but more than 22 percent of the children receiving Social Security survivor benefits.

As with disability benefits, the presence of an individual account would not do much to mitigate the benefit reductions for young survivors. First, many workers would not have time to accumulate much in an individual account before an early death. Second, if the worker's spouse is alive, the account (and the benefit offset from the account) would be available to the spouse only after the spouse retires, and so not be available (at least immediately) for the children.

for policy implementation." Strengthening Social Security and Creating Personal Wealth for All Americans, page 149 (italics in original).

${ }^{20}$ The shift to price indexing under Model 2 reduces total benefits (retirement, survivor, and disability) by 2.07 percent of payroll over the next 75 years, which is 13.4 percent of scheduled benefits over that period (under the 2001 Trustees' intermediate assumptions). Disability benefits alone amount to 2.23 percent of payroll. Assuming that price indexing affects disability benefits proportionately to retirement and other benefits, the impact of the disability reductions would be 13.4 percent of 2.23 percent, or 0.3 percent of payroll. This estimate does not include the effects on young survivors, nor does it include the benefit reductions for the disabled after their conversion to retirement benefits at the normal retirement age. For the DI component itself, the proportionality assumption may underestimate the impact on DI because the benefit reduction depends on the year of eligibility for benefits, and mean duration since benefit eligibility is lower for disability beneficiaries than for retired worker beneficiaries (both because of relatively high mortality rates for DI beneficiaries and because of the conversion of disability benefits to retirement benefits at the normal retirement age). On the other hand, the DI cost rate increases more slowly than the OASI cost rate during the 75-year projection period: Under the 2001 assumptions, the DI cost rate was expected to rise from 1.45 percent of payroll in 2001 to 2.57 percent of payroll in 2075 , whereas the OASI cost rate was expected to rise from 9.04 percent of payroll in 2001 to 16.82 percent of payroll in 2075. The 75 -year cost rate for DI is thus somewhat more front-loaded than the 75 -year cost rate for OASI, which would cause the proportionality assumption to overestimate the impact on DI (since the benefit reductions are larger for later years of initial eligibility). 


\section{Long-Career Low Earners}

For many families, living standards in retirement are considerably below those enjoyed before retirement. Social Security is supposed to mitigate the drop in living standards for families who have not saved sufficiently on their own. Concern about the potential declines in living standards upon retirement is a reason for focusing on replacement rates at all earnings levels. But the issue is of particular concern with regard to low earners, since a decline in their income could threaten the ability to secure basic necessities. This concern motivates proposals to raise Social Security benefits for low earners.

A complication in trying to target benefit increases on those who are needy is that retired worker benefits are based on a worker's earnings record; the system for determining benefits does not fully reflect family circumstances. The Supplemental Security Income (SSI) program does take into consideration family circumstances and puts a floor under the living standards of those age 65 and older, but the maximum benefit level under SSI is below the official poverty line. ${ }^{21}$ More pressing in the context of a long-term program such as Social Security, the official poverty line increases only with inflation, resulting in a poverty line that falls further and further behind average earnings over time (given positive real wage growth).

The Commission has recognized these issues and proposed to use some of the revenue saved by the benefit reductions described above to raise benefits for workers with low earnings who have had earnings in at least 20 years. The details of the proposal are shown in Table 3. The maximal percentage increase of 40 percent is not sufficient to offset the reduction in traditional benefits from price indexing for workers younger than $20 .{ }^{22}$ Unfortunately, the

\footnotetext{
${ }^{21}$ The maximum federal SSI benefit, $\$ 545$ per month for an individual and $\$ 817$ for a couple in 2002 . The official poverty threshold for an elderly couple in 2001 was $\$ 10,705$, or $\$ 892$ per month. The figure for 2002 is likely to be approximately $\$ 920$ per month. Many analysts, furthermore, believe the official poverty threshold is too low. For further discussion of the problems with the official poverty threshold, see Constance F. Citro and Robert T. Michael, ed., Measuring Poverty: A New Approach (National Academy Press: 1995). Some states supplement the federal SSI payment, but the amounts vary by state.

${ }^{22}$ Workers who are younger than 20 experience more than a 28.6 percent decline in their PIA, which is the critical threshold for determining whether benefits are higher or lower than under the current benefit formula. (Solving
} 
Commission did not provide a detailed analysis of the impact of this proposal on the distribution of income levels. ${ }^{23} \quad$ But regardless of the precise effects, the existence of the proposal underscores the Commission's valid concern about the plight of lower earners in retirement.

\section{Widows and Widowers}

Just as Social Security is designed to mitigate a decline in living standards when a worker is disabled or retires, so too it is designed to mitigate a drop in living standards of family members when a worker or retiree dies. Social Security provides benefits to the elderly spouses of deceased workers. It also provides benefits to the young children of workers who die, as discussed above. Although the Commission did not address issues raised by the deaths of workers with young children, it did make a proposal for the widows and widowers of retired workers.

Under current law, the survivor receives a benefit equal to between 50 percent and 67 percent of the combined benefits of the couple before the death. ${ }^{24}$ The Commission proposes instead that in the event of the death of a worker after retirement, the benefit of the surviving spouse would be at least as large as 75 percent of the combined benefits of husband and wife before the death. ${ }^{25}$ However, this provision would be limited to benefit increases that did not raise the benefit level above the average PIA of retired workers. In December 2000, the average PIA of retired workers was $\$ 851$, which would correspond to an annual benefit of $\$ 10,214$ if

$1.4 \mathrm{x}=1.0$ gives $\mathrm{x}=.714$, which implies a 28.6 percent decline in PIA. For long-career low-income workers younger than 20 , the specific benefit expansion is therefore more than offset by the general reduction in benefits under Model 2.)

${ }^{23}$ The impact of the proposal, while progressive, would appear to be relatively modest. Over the 75-year horizon, for example, its cost amounts to roughly 6.5 percent of the cost savings from the shift to price indexation for determining initial benefits. Furthermore, the proposal is defined in terms of a percentage of the Primary Insurance Amount (PIA), which is the benefit level received by a worker claiming benefits at the Normal Retirement Age (NRA). Thus the annual cost of the proposal gets steadily smaller relative to the annual cost savings from price indexing (since price indexing reduces the PIA by increasing amounts, which also reduces the cost of the expanded benefit).

${ }^{24}$ The survivor's benefit is reduced if the survivor claims it before the normal retirement age, and can also be reduced if the primary worker had claimed benefits before the normal retirement age (or increased if the primary worker had claimed benefits after the normal retirement age). For further discussion, see David Weaver, "The Widow(er)'s Limit Provision of Social Security," Social Security Bulletin, Vol. 64, No. 1, 2001/2002, pages 1-15.

${ }^{25}$ Starting 2009, this provision would apply for those age 62 or older. 
benefits were claimed at the normal retirement age. ${ }^{26}$ Even with this increase in survivor benefits relative to worker and spouse benefits, the steady decline from price indexation in worker and spousal traditional benefits would eventually be larger than the increase from this adjustment. Thus widow and widower benefits would eventually be lower than those scheduled in current law.

Analysts of Social Security have long been concerned about the drop in living standards of the surviving spouse upon the death of a retired worker. Indeed, surviving widows typically suffer a 30 percent drop in living standards (income relative to a measure of needs). ${ }^{27}$ Moreover, although the poverty rates for elderly married couples are approximately 5 percent, the poverty rates for elderly widows are more than three times as large. ${ }^{28}$ Basing the benefits of a survivor on the benefits that had been received by the couple is a sensible approach to the problem of trying to maintain living standards. ${ }^{29}$

\section{$\underline{\text { Actuarial Balance }}$}

The reduction in retirement, survivor, and disability benefits from the change to price indexing, combined with the modest increases in benefits for long-career low earners and some widows and widowers with low benefits, produces the impact on actuarial balance shown in Table 4. The shift to price indexing reduces benefits by so much that it is possible to devote a

${ }^{26}$ The PIA figure is taken from Table 5.C1 of the draft Annual Statistical Supplement 2001, available at http://www.ssa.gov/statistics/Supplement/2001/index.html.

${ }^{27}$ Karen Holden and Cathleen Zick, "Insuring against the Consequences of Widowhood in a Reformed Social Security System," in R. Douglas Arnold, Michael J. Graetz, and Alicia H. Munnell, Framing the Social Security Debate: Values, Politics, and Economics (National Academy of Social Insurance: 1998), pages 157-181.

${ }^{28}$ Melissa M. Favreault, Frank J. Sammartino, and C. Eugene Steuerle, "Social Security Benefits for Spouses and Survivors," in Melissa M. Favreault, Frank J. Sammartino, and C. Eugene Steuerle, eds., Social Security and the Family (Urban Institute Press: 2002), Table 6.1, page 183.

${ }^{29}$ Although the Bush Commission's proposal is a step in the right direction, restricting it to low-benefit survivors is unduly restrictive. Indeed, the cost of this proposal is only four percent of the cost savings from the reduction in benefits from price indexing. Previous proposals, for example by Burkhauser and Smeeding, would not have limited the survivor benefit expansion to those with low benefits. In particular, Burkhauser and Smeeding proposed an increase in survivor benefits for all elderly survivors, and suggested financing this increase by reducing spousal benefits, thereby tending to transfer benefits from the time when both husband and wife were alive to the time when just one was. (See Richard Burkhauser and Timothy Smeeding, "Social Security Reform: A Budget-Neutral Approach to Older Women's Disproportionate Risk of Poverty," Center for Policy Research, Maxwell School, Syracuse University, 1994.) The Gramlich plan from the 1994-1996 Advisory Council proposed a similar approach. "Option II: Publicly-Held Individual Accounts," Report of the 1994-1996 Advisory Council on Social Security, Volume I: Findings and Recommendations, pages 28-29. 
tenth of the cost savings to increased benefits for some groups with low benefits and still restore actuarial balance. Moreover, since benefit levels are so much lower than scheduled benefits after 75 years and since further benefit reductions would follow in later years, this system would be in permanent balance: The passage of time itself, with unchanged economic and demographic assumptions, would not produce larger deficits.

In summary, Model 2 partially substitutes price indexing for wage indexing in determining initial benefits. It represents a shift in the focus of Social Security away from its role in preserving living standards of workers and their families at times of retirement, disability, or death and to a lesser role of providing benefits that would, on average, lag behind earnings. This model shows clearly the implications of trying to close the long-term Social Security actuarial deficit solely by benefit reductions. Although it incorporates only one particular pattern of how benefits could be reduced for workers born in different years, it illustrates the broader implications of closing the actuarial deficit purely by benefit reductions. Not surprisingly, such an approach involves dramatic reductions relative to scheduled benefits. No funding was provided to lessen these dramatic reductions for beneficiaries with little or no ability to draw upon an individual account, such as the disabled and young survivors.

\section{B. Model 3 Proposals for Traditional Benefits and their Financing}

Model 2 is an example of how much benefits must be reduced to restore actuarial balance if there are no additional revenues devoted to Social Security. Model 3 instead assumes that onethird of the actuarial deficit will be covered by new dedicated revenues. It then eliminates the rest of the actuarial imbalance by reducing monthly benefits in line with improvements in mortality (i.e., it reduces monthly benefits to fully offset the cost of providing benefits for longer expected lives in retirement) along with additional reductions for early retirees and high earners.

Life expectancy is expected to continue to increase in the next 75 years. Such increases have long been part of the projections of the Office of the Chief Actuary at Social Security. ${ }^{30}$

\footnotetext{
${ }^{30}$ The Social Security projections have been criticized by some as underestimating the future decline in mortality rates. For example, the 1999 Technical Panel on Assumptions and Methods of the Social Security Advisory Board argued that the Social Security actuaries underestimate the likely reduction in mortality rates and therefore also
} 
That raises the question of whether the structure of Social Security should reflect this expectation of longer life expectancies. To some degree, Social Security already reflects increasing life expectancies. The discussion surrounding the 1983 reforms related the legislated increases in the normal retirement age (NRA) to projected increases in life expectancy. Nonetheless, it remains a legitimate question to ask whether Social Security should be modified further in response to the expected increases in life expectancy.

First, we can ask how an individual might sensibly adapt if he or she learned early in a career that life expectancy was longer than had been previously thought. Such an individual would recognize that the previous plan of (1) consumption and saving while working, (2) an age of retirement, and (3) a consumption plan after retirement was no longer feasible. ${ }^{31}$ Given the increase in life expectancy, it would no longer be possible to consume as much each year during a career, retire at the same age, and consume as much each year during retirement. A sensible approach would have the individual adjust all three margins that are available. In other words, a sensible individual would save somewhat more while working (consume somewhat less), work somewhat longer, and consume somewhat less per year in retirement.

Social Security allows individuals to enjoy larger monthly benefits by delaying the start of benefits - so the deferral option is already incorporated in Social Security. Indeed, for a typical 62-year-old worker (which is the most common age for claiming benefits), the increase in benefits from a delayed start roughly offsets the loss in benefits. ${ }^{32}$ For Social Security to include the other two responses to a longer expected life would call for increased payroll taxes and lower benefits. Indeed, one could design a package of slowly increasing taxes and a slowly decreasing benefits formula that could balance these two responses. The Commission did not approach the issue in this way, however.

underestimate future life expectancies. 1999 Technical Panel on Assumptions and Methods (Washington: November 1999).

${ }^{31}$ Another possible margin is to reduce planned bequests.

${ }^{32}$ For further discussion of the actuarial adjustments in Social Security and their effects on claiming behavior, see Courtney Coile, Peter Diamond, Jonathan Gruber, and Alain Jousten, "Delays in Claiming Social Security Benefits," NBER Working Paper W7318, August 1999. 
After recognizing the trend increase in life expectancy, Model 3 proposes to reduce scheduled benefits to fully offset the impact of the currently expected increase in life expectancy on Social Security outlays. The particular proposal is to reduce benefits in line with actuarial calculations for each new group of potential retirees. Given current actuarial projections, this calls for a reduction in scheduled benefits of $1 / 2$ of 1 percent for each later year of birth. The implications of such reductions are shown in Table 5. For example, a current 35-year old would have a 9.5 percent cut relative to scheduled benefits under this proposal. A current newborn would experience a 24.1 percent reduction.

Note that the Commission's approach would be implemented even in years when the normal retirement age is being increased under current law, supposedly also in response to increased life expectancy - a double reduction for the same cause. Presumably both of these reductions should not happen at the same time. Whatever the motivation or justification, the benefit reductions from this provision are projected to happen at roughly one-half the rate of benefit reductions in Model 2. ${ }^{33}$

\section{$\underline{\text { Actuarial Reduction and Delayed Retirement Credit }}$}

The benefits for a retiring worker depend on the age at which a worker's benefits start. If a worker claims benefits at the NRA, which is slowly increasing from age 65 to age 67 under current law, benefits are equal to the PIA. If a worker claims benefits at an earlier age, the benefits are reduced by a factor that is called the actuarial reduction. When the NRA was 65, a worker claiming benefits at age 62 would have received 80 percent of the PIA. Under current law, claiming benefits at age 62 results in 77.5 percent of the PIA since the NRA is now above age 65; as the NRA increases further under current law, that percentage will decline to 70 percent (for workers turning age 62 in 2022 or later). Model 3 includes a further reduction of benefits for workers who start their benefits before the NRA, as shown in Table 6.

\footnotetext{
${ }^{33}$ The procedure for updating the benefit adjustments for mortality shifts is somewhat unclear. In particular, the Report states that the "adjustment would be based on actual changes in period tables 10 years prior." It remains unclear whether the adjustment would be automatic, left to the discretion of the actuaries, or require legislative changes.
} 
Since most workers retire before the normal retirement age, they would experience larger benefit reductions than shown in Table 5. In 1999, for example, 69 percent of men and 73 percent of women claimed benefits before age $65 .{ }^{34}$ Table 7 shows the reductions for retirement at age 62, combining the adjustments for life expectancy with the change in the actuarial reduction. . (Model 3 also incorporates other changes described below.) While a current 35-year old would have a 9.5 percent reduction from scheduled benefits if claiming benefits at the NRA, the reduction would be 18.6 percent if benefits were claimed at age 62 . A newborn today would experience a 24.1 percent reduction in benefits if claiming benefits at the NRA, and a 31.7 percent reduction if claiming benefits at age 62. Reducing benefits for 62-year olds by more than for workers retiring at later ages is an incentive to continue working. ${ }^{35}$

Once a worker reaches the NRA, benefits can be claimed whether the worker retires or not. ${ }^{36}$ If a worker delays the start of benefits, benefits are larger once they do start because of the Delayed Retirement Credit (DRC). Under Model 3, the Delayed Retirement Credit is increased relative to current law. In the absence of major behavioral changes, however, the increase is likely to affect very few workers - only those who have not claimed benefits already. In 1999, only 7 percent of new retirement benefits were claimed by workers age 66 or older. ${ }^{37}$ Moreover, since benefits can be claimed or delayed whether working or retired, the increase in benefits for delays beyond the NRA does not noticeably affect the incentive to continue working.

\section{$\underline{\text { Lower Benefits for High Earners }}$}

Model 3 includes a reduction in the benefit formula for high earners, with the marginal benefit rate going from 15 percent to 10 percent for the highest tier of covered earnings. ${ }^{38}$ (In other words, an increase of $\$ 1$ in averaged indexed monthly earnings in the highest earnings

\footnotetext{
${ }^{34}$ Committee on Ways and Means, 2000 Green Book, Table 1-13, page 53 (Government Printing Office: Washington, 2000).

${ }^{35}$ Of course, such an incentive could also have been achieved by increasing benefits for those retiring later rather than decreasing benefits for those retiring sooner.

${ }^{36}$ Before the NRA, an earnings test limits the ability of workers to claim benefits while continuing to work. See Jonathan Gruber and Peter Orszag, "What To Do About the Social Security Earnings Test," Issue in Brief Number 1, Center for Retirement Research, Boston College, July 1999.

37 Committee on Ways and Means, 2000 Green Book, Table 1-14, page 53 (Government Printing Office: Washington, 2000).

${ }^{38}$ This is phased in between 2009 and 2028.
} 
range would raise the monthly benefit level by 10 cents, rather than 15 cents as under current law.) This reduction is a progressive contribution to actuarial solvency: It reduces benefits by more for higher earners than for lower earners, and is expected to eliminate slightly less than 10 percent of the current 75 -year actuarial imbalance in the program.

\section{Disabled Workers and Surviving Children}

As with Model 2, the benefit reductions are assumed to apply to the children of deceased workers and to the disabled and their dependents for actuarial scoring. Thus a 20-year old worker today becoming disabled at age 40 (in 2022) would experience a 7 percent reduction in benefits, and a worker becoming disabled in 2075 would experience a 29 percent reduction in benefits (Table 8). The same effects would apply to the children of deceased and disabled workers. As with Model 2, the Commission failed to provide funding for mitigating these effects.

\section{$\underline{\text { Long-Career Low Earners and Widows/Widowers }}$}

As under Model 2, Model 3 contains proposals to increase benefits for low earners and surviving spouses with low benefits. ${ }^{39}$ With the benefit reductions in Model 3 being smaller than benefit reductions in Model 2, the increase in benefits for low earners is smaller in percentage terms (since the expansion is intended to provide at least the poverty level of income, and since base benefits are higher under Model 3). The details of this proposal are in Table 9. The maximal percentage increase of 18 percent is not sufficient to offset the reductions in traditional benefits for workers who are 22 or younger who claim benefits at the normal retirement age or workers younger than 43 who claim benefits at age 62. The proposal for surviving spouses is the same as in Model 2. Even with this increase in survivor benefits relative to worker and spouse benefits, the steady decline in traditional benefits for workers and spouses would eventually be larger than the increase from this adjustment. Thus widow and widower benefits would eventually be lower than those scheduled in current law. The cost of the two proposals is roughly the same for Model 3 as for Model 2.

\footnotetext{
${ }^{39}$ Starting in 2009 , the provision for survivors would apply to those age 62 or older.
} 


\section{$\underline{\text { Actuarial Balance }}$}

The reduction in retirement, disability, and survivor benefits from indexing the benefit formula for life expectancy, combined with the changes in the actuarial reduction factor, delayed retirement credit, benefits for high earners and the increases in benefits for long-career low earners and widows and widowers with low benefits, generates the 1.31 percent of payroll improvement in actuarial balance shown in Table 10. However, these changes, by themselves, are not sufficient to restore actuarial balance: The actuarial imbalance remaining amounts to 0.55 percent of payroll.

To eliminate the remaining imbalance, Model 3 proposes an increase in revenues dedicated to Social Security, sufficient to cover roughly one-third of the actuarial deficit. The Commission does not recommend any particular source for these revenues. However, it does score the dedicated revenues as if they came from an increase in the maximum earnings subject to payroll taxation and a transfer of some of the revenue from the income taxation of benefits from Medicare to Social Security. ${ }^{40}$ The Commission does not indicate how to avoid deterioration in Medicare's financial position in response to the loss of revenues under this approach. $^{41}$

As with Model 2, since benefit levels are so much lower than scheduled benefits in 75 years and since further benefit reductions would follow in later years, this system would not go

\footnotetext{
${ }^{40}$ The scoring of the transfers assumed that the percentage of covered earnings subject to tax increased to 86 percent between 2005 and 2009, and was then maintained at that level thereafter. The revenues transferred from Medicare to Social Security were phased in between 2010 and 2019. Under current law, Social Security beneficiaries with modified adjusted gross income above $\$ 25,000$ if single or $\$ 32,000$ if married have part of their Social Security benefits included in income for tax purposes. For income above these levels, 50 percent of Social Security benefits are included in income for tax purposes. The income tax derived from including these benefits in taxable income is credited to the Social Security Trust Fund. For the highest-income beneficiaries (those with incomes above $\$ 34,000$ if single or $\$ 44,000$ if married), up to 85 percent of Social Security benefits can be included in income for tax purposes. Any income tax derived from including more than 50 percent of benefits in taxable income is credited to the Medicare Trust Fund.

${ }^{41}$ In what may be the only dissenting word in the Report, "Some members of the Commission believed that a substantial portion of this $0.63 \%$ should come from an increase in the payroll tax base....However, this suggestion was deemed inconsistent with the principles in the executive order establishing the Commission." (footnote 41, page 131).
} 
out of balance just from the passage of time (assuming unchanged economic and demographic assumptions).

\section{Introduction of Individual Accounts}

Following the charge to the Commission, the Report presents a design for individual accounts that is used in all three reform models. We begin by considering the general structure of the proposed accounts. Then we consider the effects on actuarial balance, Trust Fund balances, Treasury borrowing from the public, and worker assets and benefits.

In broad terms, workers under all three plans would be given the option of having part of their payroll taxes deposited into individual accounts. The individual account system would involve two components: the individual account assets, which would contain a worker's deposits and the accumulated earnings on them, and a "liability account." If a worker chose to participate in the individual account system, the portion of his or her payroll taxes diverted into the account would accumulate during the worker's career, and be available to the worker upon retirement. Since the revenue diverted to this account would reduce the financing available to the traditional Social Security system, a liability account would also be created. This liability account accumulates the amounts diverted plus interest and so determines the debt owed back to Social Security because of the diverted funds. Upon retirement, the debt would be repaid by reducing traditional Social Security benefits.

\section{A. Account Specification - Asset Accumulation}

In all three models, workers are given the option of having part of their payroll taxes deposited into their individual accounts. These diverted funds are used to purchase assets from a limited menu of alternatives, with one menu organized by the government for those with small accounts (Tier I) and additional choices from private providers for those with larger accounts (Tier II). The Tier I structure is modeled on the Thrift Savings Plan that handles defined contribution accounts for federal civil servants. Under this tier, workers could choose among 
nine different mutual funds. ${ }^{42}$ For those with balances above $\$ 5,000$ (adjustable in the future, but without specified rules), there would be a further option of moving the entire balance out of Tier I and investing with a private fund manager. These fund managers could offer the same options as in Tier I and could offer additional options, although the latter would be restricted to be widely diversified funds.

In assessing the implications of the balances in these accounts, the Commission assumes that Treasury bonds would have a 3 percent gross annual real yield, corporate bonds a 3.5 percent gross annual real yield, and stocks a 6.5 percent gross annual real yield. All three numbers are reasonable and consistent with the 3 percent real interest rate assumption used by the actuaries in assessing the evolution of the Trust Fund. ${ }^{43}$ In converting gross yields to yields net of transaction costs, the Commission assumes an annual charge of 30 basis points $(0.3$ percent) of assets under management. Such an administrative cost cumulatively consumes roughly six percent of the account balance at the end of a 40 -year career relative to no administrative charges. Several issues arise in considering this estimate for the administrative charges. $^{44}$

First, in the early years, setting up the initial set of accounts would involve additional one-time costs, and the assumed 30 basis point charges could not credibly cover these costs. The Commission ignores this short-run problem, focusing on a long run when the accounts would be larger.

\footnotetext{
${ }^{42}$ An individual could put all of the account into one of the three balanced funds (which combine equities with fixed-income assets, and vary in the percentage in stocks). Or an individual could divide the account among six mutual funds (large stocks, small stocks, foreign stocks, corporate bonds, Treasury bonds, and inflation-indexed Treasury bonds). Information about the Tier I accounts would be available online and by automated phone, but written statements would be sent only once per year. Changes to the allocation of either existing balances or new deposits would also be allowed once per year. Collection of revenues and allocation to individual accounts would be done in conformity with current payroll tax collection, implying that there would be significant lags between the transmission of taxes by the worker's employer and when the funds were invested as the worker designates. In addition, individuals paying taxes at different times of the year would all be treated as if they paid taxes at the same time.

${ }^{43}$ The assumption on stocks does not address the likelihood that stock returns will be much lower in the short run than in the long run. On stock returns, see Peter A. Diamond, "What Stock Market Returns to Expect for the Future?" Social Security Bulletin, 2000 and Social Security Advisory Board, Estimating the Real Rate of Return on Stocks Over the Long Term, Washington, DC, August 2001.

${ }^{44}$ For more discussion of administrative costs, see Peter A. Diamond, "Administrative Costs and Equilibrium Charges with Individual Accounts," in John Shoven (ed.), Administrative Costs and Social Security Privatization
} 
Second, the bulk of the costs of administering the accounts would be fixed costs: That is, they would be costs per account, not costs that vary with the size of the accounts. The cost per dollar balance (which is the metric consistent with the 30 basis point figure) would thus fall as the account size increased. Thus one critical question is the average size of the accounts. In turn, the average size of the accounts depends on the extent to which movements from Tier I to Tier II lower the average size of the accounts in Tier I. If everyone were to move to Tier II when reaching the $\$ 5,000$ threshold, 30 basis points would be less than $\$ 15$ per year (.003 multiplied by $\$ 5,000$ ), which would be clearly inadequate. If no one were to move to Tier II, the 30 basis point administrative cost figure seems reasonable for the long run for a level of services roughly paralleling those offered by the TSP. However, it is plausible that some workers would move to Tier II, which would make the administrative cost assumption less realistic. Furthermore, if services were to be greater than those offered by TSP, costs would be greater than assumed.

The TSP parallel highlights an essential element in the cost assumption: the lack of funding for significant financial education. In the TSP, it is federal agencies, not the TSP, that provide the bulk of the financial education to contributors. Yet the Report writes that:

"The Governing Board must bear the primary responsibility for providing participants with the necessary financial information..." (page 42)

The experience with $401(\mathrm{k})$ accounts in the United States is that effective financial education is expensive. $^{45}$ The experience in the United Kingdom also suggests that providing financial education in the context of voluntary individual accounts is costly. ${ }^{46}$ Many of the workers who would most need financial education under an individual account system in the United States have little experience with financial markets. The financial education task required may therefore be extensive. Indeed, surveys show limited financial understanding: only half of

(University of Chicago Press: Chicago, 2000) and Issues in Privatization of Social Security, Report of the Panel on Privatization of Social Security (MIT Press: Cambridge, 1999).

${ }^{45}$ See Patrick Bayer, B. Douglas Bernheim and John Karl Scholz, "The effects of financial education in the workplace: Evidence from a survey of employers," NBER Working Paper 5655, 1996. 
Americans know the difference between a stock and a bond, only 12 percent know the difference between a load and no-load mutual fund, and only 16 percent understand the details of an Individual Retirement Account (IRA). ${ }^{47}$ There is thus a clear contradiction between financing a reasonable level of education out of the charges on the accounts and the assumed level of 30 basis points. The Commission did not indicate any other source of funding for this educational responsibility.

A separate issue involves whether the low level of services underlying the cost assumption is reasonable on political economy grounds. In particular, the Commission proposes that portfolio choice be restricted as described above, which helps to reduce administrative costs. But the portfolio alternatives would be far less extensive than the much wider set of investment opportunities that many workers currently have access to in their 401(k) accounts. A critical question for the viability of the Commission approach and its cost estimate is whether Congress would sustain the rule of such limited investment opportunities even if it were passed initially. Particularly given the Commission's vocabulary that a virtue of individual accounts is that the workers own them, some workers will undoubtedly argue that they should have access to the investments of their own choice. Indeed, in the discussion of tightening restrictions on 401(k) investments after the Enron meltdown, President Bush's Treasury has argued:

"Assets in 401(k) accounts belong to the workers and the government should not arbitrarily restrict how they choose to invest their funds...,48

Applying the same logic to individual accounts would have the Treasury opposing the restrictions of the Commission. Furthermore, the existence of Tier II suggests that the Commission itself recognized the political difficulties associated with severe restrictions on investment choices. In any case, the political viability of the proposed restrictions is unclear. And in the absence of such investment restrictions, both the understatement of the cost estimate

\footnotetext{
${ }^{46}$ For a more detailed discussion of the U.K. example, see Mamta Murthi, J. Michael Orszag, and Peter R. Orszag, "Administrative Costs under a Decentralized Approach to Individual Accounts: Lessons from the United Kingdom," in R. Holzmann and J. Stiglitz, eds., New Ideas About Old Age Security (The World Bank: 2001).

${ }^{47}$ Arthur Levitt, "The SEC Perspective on Investing Social Security in the Stock Market," John F. Kennedy School of Government, Harvard University, October 19, 1998.

${ }^{48}$ Report of the Department of the Treasury on Employer Stock in 401(k) Plans, February 28, 2002.
} 
and the lack of adequate funding to educate workers about investment choices become even more important.

\section{B. Account Specification - Liability Accumulation}

Since the revenue contributed to an individual account would not be paid into the traditional Social Security system, a worker's future traditional Social Security benefit would be reduced to reflect the contributions made into the individual account. In particular, the Social Security Administration (SSA) would keep records of the amount of payroll tax revenue that each worker diverted to an individual account. Each year, SSA would update the cumulative amount diverted and compute an interest charge on the balance outstanding in this calculation. The balance (inclusive of the interest charge) would represent a liability, resulting in a decrease in benefits to pay off the liability for the worker after retirement or, in relevant cases, for the divorced spouse or the surviving spouse of the worker. Thus we refer to this account as the liability account that is paired with the asset account financed by diverted payroll taxes.

When a single worker retires, the accumulated balance in the liability account would trigger a reduction in traditional monthly Social Security benefits. Specifically, the monthly benefit reduction would be computed so that the present value of the reduction would be equal to the accumulated balance in the liability account, calculated at the same interest rate as was used to accumulate the liability balance. In other words, the reduction in monthly benefits would be just enough, in expected present value, to pay off the liability created by diverting payroll taxes given this interest rate. ${ }^{49}$

For a married worker, the reduction in benefits would be taken out of all benefits based on the worker's record, including both spouse benefits and survivor benefits. However, the Report does not indicate how such a calculation could be readily undertaken if husband and wife are not both retired when the calculation is done. Since future work by one spouse not already

\footnotetext{
${ }^{49}$ The net result from the actual individual account and the liability account/benefit reduction system is similar to an investor who borrows in order to purchase an asset. It differs from buying stocks on margin in that there would not be a margin call if the assets (in the actual individual account) were worth less than the liability (in the liability account).
} 
retired can readily alter whether any spouse or survivor benefits would subsequently be paid, in practice the calculation can not be done accurately family by family.

If a married worker dies before retirement, the surviving spouse would inherit both the assets in the worker's individual account and the liability the worker has accumulated in the liability account. In this case, the liability would be paid off out of the survivor's eventual benefits, whether those are survivor benefits or the survivor's own worker benefits. A spouse can inherit an account that is worth more or less than the liability, if the realized return on the assets is more or less than the interest rate used in accumulating the liability.

In the event of divorce, the amounts that the accounts of husband and wife have accumulated during marriage (deposits plus earnings) are divided between the divorcing husband and wife. The amounts in the liability accounts that have accumulated during marriage are also divided. The amount received in transfer in the individual asset account could be more or less than the amount received in transfer in the individual liability account.

If a worker dies before retirement without a living spouse, the amount in the individual asset account is distributed to the heirs, but the amount in the individual liability account is not distributed. Thus, the accounts come with some implicit life insurance that benefits heirs in the absence of a surviving spouse.

\section{Account Specification - Benefits}

The Commission proposes that there be no access to account balances before retirement. In contrast, most workers currently enjoy some form of access to the balances in their 401(k) accounts prior to retirement. A critical question for the viability of the Commission approach is whether Congress would sustain the prohibition on pre-retirement access even if it were initially adopted. Again, the Commission's vocabulary suggesting that a virtue of individual accounts is that the workers own them may cause political difficulties in perpetuating such a prohibition: Workers will likely argue that they should indeed have earlier access. At the beginning, such an 
argument may be made only in hardship cases - such as a terminal disease. Over time, this might evolve into withdrawals for education or first-time home purchases, or into an ability to borrow against an account. Such pre-retirement liberalization would then severely undercut the role of Social Security as financing retirement. Indeed, the Report recognizes that it would be very difficult to hold the line politically if any early access were allowed for hardship.

Upon retirement, the balance in the individual account could be used to purchase an annuity. If the worker is married, the default is an annuity that continues to pay two-thirds of the monthly amount to a survivor in the event of the death of either husband or wife. The annuity might pay benefits that are indexed for inflation, as are Social Security benefits. Or the annuity might be variable, paying an amount that varies with the returns on a particular underlying portfolio. The default can be overridden for a different annuity or limited monthly withdrawals if both husband and wife agree. In addition, some or all of the amount can be taken as a lump sum provided that both spouses agree and the total of benefits (traditional and those annuitized from funds in the account) are large enough to keep the worker and spouse out of poverty. This approach to annuitization reflects the Commission's concern about poverty, as well as its relative lack of concern about declines in income for those above the poverty line.

\section{Account Specification by Model}

The three models differ in details in the design of the individual accounts, as summarized in Table 11. In Model 1, the account size is 2 percentage points of payroll. The interest rate used for accumulating liabilities is 3.5 percent above inflation (or 50 basis points above the expected real yield on Treasury bonds given current projections). By charging an interest rate above the return on Treasury bonds, Social Security gains resources (in expectation) over the full lifetimes of individuals choosing these accounts. The 50 basis point excess in return is partially offset by the provision of implicit life insurance, in that the liabilities are cancelled in the event of the death of a worker before retirement without a living spouse.

In Model 2, the accounts are larger than in Model 1 for some workers and smaller for others. In particular, Model 2 allows a diversion of 4 percent of earnings into the individual 
account, but only up to a limit of $\$ 1,000$ (with the $\$ 1,000$ constraint indexed to average wages). The $\$ 1,000$ constraint would bind at an earnings level of $\$ 25,000$, so all workers earnings more than $\$ 25,000$ would be bound by that level. Comparing this with Model 1 , we see that the $\$ 1,000$ deposit (the constraint under Model 2) for workers earning more than $\$ 50,000$ per year is smaller than 2 percent of earnings (the constraint under Model 1).

Although Model 1 seeks to make a small profit for the Social Security system from the individual accounts by charging an interest rate above the Trust Fund rate, Model 2 subsidizes the accounts by charging an interest rate projected to be one percent below the return on Treasury bonds (as well as providing the same life insurance as mentioned above). ${ }^{50}$ Moreover, the larger the deposit, the larger the subsidy received.

To see the magnitude of the subsidy, consider as just one example the "scaled medium earner" worker who makes nearly the maximum allowable contribution under Model 2 and claims benefits at age 62 in 2072..$^{51}$ (We chose age 62 because most beneficiaries currently claim at that age. We chose the year 2072 to conform to the examples in the Report showing results for those claiming benefits at age 65 in 2075; those claiming benefits at age 62 in 2072 are in the same cohort as those claiming benefits at age 65 in 2075 . The results are generally similar for other ages and cohorts.) The cost to the Trust Fund can be calculated using the rate of return on Treasury bonds that the Trust Fund would be holding if there were no diversion. But the repayment to the Trust Fund is based on the interest rate for liabilities chosen by the Commission. To measure the implications of the difference in interest rates, we compare the annual benefit that could be financed from the Trust Fund if there were not diverted taxes with

\footnotetext{
50 The Commission's Report argues that "Personal accounts can also contribute towards the fiscal sustainability of the Social Security system." President's Commission to Strengthen Social Security, Strengthening Social Security and Creating Personal Wealth for All Americans, page 11. However, the accounts created in Models 2 and 3 do not do so.

${ }^{51}$ For these purposes, we use the medium earning "scaled worker" developed by the Social Security actuaries. This is a worker with a realistic age-earnings profile and an earnings level in the middle of the earnings distribution. See Orlo R. Nichols, Michael D. Clingman, and Milton P. Glanz, "Internal Real Rates Of Return Under The OASDI Program For Hypothetical Workers," Actuarial Note Number 144, Office of the Chief Actuary, June 2001. Following the 2001 Trustees report, we also assume wages grow at one percent annually in real terms, as opposed to the 1.1 percent in the 2002 report. This medium earner is constrained by the $\$ 1,000$ (indexed) limit on contributions in all but seven of his working years.
} 
the decrease in benefits that would happen under the liability account system, which equals the repayment to the Trust Fund.

Accumulating the contributions of the scaled medium earner at 3 percent and annuitizing them on an actuarially fair basis assuming a joint-and-two-thirds-survivor benefit, we have an expected projected initial annual cost to Social Security of \$6,499 in 2001 dollars. Accumulating these contributions instead at 2 percent (as under Model 2) and again annuitizing them (using a 2 percent interest rate as under Model 2), we have a projected initial annual repayment to Social Security of $\$ 4,612$ (ignoring the implicit life insurance and the impact on the income taxation of benefits from traditional benefits and the individual account withdrawals). The difference between the two -- $\$ 1,887$ per year -- is the subsidy given to the medium earner after retirement from the accounts. ${ }^{52}$ At retirement, the present value of the subsidy to the individual accounts, assuming a real interest rate of 3 percent and that the surviving spouse receives a two-thirds annuity, amounts to $\$ 33,559$ (see Table 12$).^{53}$

A worker making smaller contributions receives less of a subsidy. The "scaled lower earner" used in analyses by the actuaries, for example, would receive a subsidy of $\$ 1,120$ per year upon retirement in 2072, which produces a present value subsidy of slightly under $\$ 20,000$ at retirement. Thus the use of an interest rate below the rate earned by the Trust Fund gives a larger subsidy to high earners more than to low earners. (The difference between the subsidy to the medium-earner and the subsidy to the higher-earner is limited by the $\$ 1,000$ cap.) ${ }^{54}$

The same basic effects hold with regard to Model 3. That model mandates an additional contribution in order for a worker to divert part of the payroll tax into an individual account. The

\footnotetext{
${ }^{52}$ For workers claiming benefits at age 62 in 2049 , the subsidies amount to $\$ 1,543$ for the medium-earner, $\$ 915$ for the lower-earner, and $\$ 1,628$ for the higher-earner (all in 2001 dollars).

${ }^{53}$ These subsidies are computed on a pre-tax basis. The subsidy would be somewhat smaller on a post-tax basis, at least without adjusting for risk, since the individual account yield exceeds the Trust Fund interest rate. The difference between the account yield on the Trust Fund interest rate would be partially recaptured by the Social Security system since withdrawals from the accounts would be subject to income taxation in a manner parallel to Social Security benefits.

${ }^{54}$ The Commission states that "lower-wage workers would benefit the most, because of the progressive formula for funding the accounts." (Strengthening Social Security and Creating Personal Wealth for All Americans, page 130.) With capped annual contributions, low earners gain more in percentage terms than high earners, but less in absolute terms.
} 
size of the account is 2.5 percent of taxable earnings, up to $\$ 1,000$ (with the $\$ 1,000$ figure again indexed by average wages). In order to divert these funds, however, the worker is required to make an additional deposit to the account of one percent of taxable earnings. The Report anticipates that general revenues will be used to subsidize the contributions of low earners, but the details are not specified and the estimated cost to the Treasury is not included in the overall analysis. ${ }^{55}$ The actuaries report the cost of the general revenue subsidies for these contributions to be 0.15 percent of taxable payroll over the next 75 years, assuming two-thirds of workers start accounts. ${ }^{56}$ Although the diversion is capped at $\$ 1,000$, it appears that the required additional contribution is not similarly capped.

The additional one percent contributions would not be counted in the liability account. The base contributions, however, would be. The interest rate on the induced liability is 50 basis points ( 0.5 percent) below the Treasury rate. Thus, as in Model 2, the accounts are being subsidized in the sense that the Trust Fund would lose money over the lifetime of a worker choosing to divert funds into the accounts. Doing the same calculation as above, the subsidy to the average earner is $\$ 843$ per year upon retirement at age 62 in 2072. At retirement, the present value of the subsidy amounts to $\$ 15,000$ (Table 13). Again, the subsidy is larger for a medium worker than a low earner.

\section{E. Actuarial Balance}

The subsidies to individual accounts under Models 2 and 3 mean that the partial effect of the individual account option is to worsen Social Security's long-term actuarial balance when considering the effect over a worker's lifetime. ${ }^{57}$ Furthermore, the more people who divert funds into the individual account, the worse the impact. In addition to this adverse effect, the individual accounts create a cash-flow problem since payroll tax diversion precedes benefit

\footnotetext{
${ }^{55}$ The Treasury also loses revenue from an additional tax-favored retirement savings vehicle.

${ }^{56}$ Memorandum from the Office of the Chief Actuary, page 14.

${ }^{57}$ This contradicts various assertions within the Report. For example, the Report argues that "every dollar invested in a personal account reduces the cost of future Social Security payments by one dollar, plus the offset rate of interest that is proposed for each plan (ranging from 2 percent to 3.5 percent after inflation)... So long as the personal account earns a return higher than the offset rate, both Social Security and the individual come out ahead." Strengthening Social Security and Creating Personal Wealth for All Americans, page 149. The final sentence is
} 
reductions by many years. The traditional 75-year horizon affects the size of the actuarial effect of the accounts but is not the only reason that the effect is negative. Even on a permanent basis, the diversion of revenue into individual accounts under Models 2 and 3 causes deterioration in Social Security's financial balance because of the subsidy provided to the accounts.

If all workers choose to contribute to the individual accounts under Model 2, the cost of the contributions over the next 75 years amounts to 2.2 percent of payroll. ${ }^{58}$ The benefit reductions from the liability accounts over the next 75 years amount to 1.1 percent of payroll. Social Security also gains less than 0.05 percent of payroll from the income taxation of withdrawals from the individual accounts (net of the loss of income taxation from the reduction in benefits through the liability accounts). ${ }^{59}$ The net effect of the individual accounts by themselves is thus to worsen Social Security's 75-year balance by 1.1 percent of payroll.

The 75-year actuarial figures do not reflect the full long-term impact of the diversion of funds to the individual accounts during the 75-year period. To see why, consider what would happen with a real interest rate on liability accounts of 3 percent, so that diverting a dollar into an individual account would not affect the long-term fiscal condition of the Social Security system (since the rate on liability accounts would be equal to the Trust Fund interest rate). ${ }^{60}$ But if the dollar is diverted into the individual account within the traditional 75-year window, whereas the offset to benefits would not occur until after the end of the 75-year window, the diversion will cause deterioration in the 75-year actuarial balance as measured by the actuaries. The reason this

simply incorrect, because it ignores the interest earnings that the Social Security Trust Fund could have enjoyed on the diverted funds.

58 Once in effect, the contributions amount to 2.4 percent of taxable payroll. The contributions would not begin until 2004, however. Payroll between 2004 and 2075 amounts to 94 percent of payroll between 2001 and 2075 (in present discounted value). The cost of the contributions over the entire 75-year period is therefore approximately 94 percent of 2.4 percent, or 2.2 percent after rounding.

${ }^{59}$ Under the intermediate projections of the actuaries, the income taxation of benefits under the scheduled benefit system is expected to produce revenue equal to 0.7 percent of taxable payroll over the next 75 years. See 2002 Annual Report of the Board of Trustees of the Federal Old-Age and Survivors Insurance and Disability Insurance Trust Funds, Table IV.B8, page 68. Under Plan 2, the distributions from the individual accounts would amount to 1.9 percent of payroll, and the offsets would amount to 1.1 percent of payroll. The net change in taxable benefits is therefore approximately 0.8 percent of payroll, or 5 percent of the total projected benefits under current law. Assuming proportionality, the implication is that the income taxation on the individual accounts would produce a gain (net of the lost tax revenue due to the benefit offsets) of approximately 0.04 percent of taxable payroll $(0.05 * 0.7=.04)$.

${ }^{60}$ The actuarial effect may be slightly different from zero because, for simplicity, we are ignoring the effects of the life insurance component and the impact on the income taxation of benefits. 
result obtains is that in computing the actuarial balance, the actuaries do not include the accumulated balance in the liability accounts at the end of the 75-year period. We can, however, adjust the 75-year figures for those accumulated balances, which may help to provide a picture of the longer-term impact of the accounts than the official 75-year figures alone. The adjustment needs to reflect the fact that the balances accumulate at a lower interest rate and are also converted into benefit reductions using the same lower interest rate.

As Table 14 reports, the actuarial impact of the individual accounts (exclusive of general revenue transfers) is still negative once an ending liability adjustment is made, although the size of the 75-year impact on balance falls significantly under both Models. ${ }^{61}$ Under Model 2 with full participation, the impact on actuarial balance is reduced from -1.08 to -0.62 by adjusting for the value to Social Security inherent in the balances in the liability accounts. Under Model 3 with two-thirds participation, the impact is reduced from -0.44 to -0.12 by this adjustment. The presence of a net cost even after adjusting for the ending liability balances is not surprising, since the rate earned by the Trust Fund from the liability accounts is below the Treasury rate earned on bonds for both Model 2 and Model 3. The actuarial effect of the accounts is lower under Model 3 since the interest rate on liabilities under Model 3 is only 50 basis points below the Trust Fund rate and the assumed participation rate is lower.

Comparing Tables 14 and 4 also illustrates that the cost of the subsidies to the individual accounts (even after accounting for the ending liability balances) -- 0.62 percent of taxable payroll -- is substantially larger than the cost of the progressive benefit expansions provided to low earners and to widows combined under Model 2, which is 0.21 percent of payroll. For

\footnotetext{
61 The analysis is complicated because the actuaries computed the accumulated dollar balance in the liability accounts at the end of the projection period, not the value to Social Security of those balances. Since the liability accounts would continue to accumulate and then be annuitized at the lower rate for liabilities outside the 75-year projection period, their value to Social Security is reduced. Since we cannot compute the correct figure precisely, Table 16 presents two sets of figures: one with no adjustment to reflect the diminishment in value to Social Security from the operation of the lower rate on liabilities outside the projection period and another that provides a rough adjustment. We estimate that the value of $\$ 1$ in the liability account under Model 2 is worth approximately 75 cents to Social Security in present value, assuming the mean balance is owed by a worker approximately 45 to 50 years in age. Under Model 3, \$1 in the liability account is worth approximately 85 cents to Social Security in present value under the same assumption. Even if the full balance in the liability accounts were counted as reducing Social Security obligations, which would provide a lower bound on the actual subsidy, a net cost remains.
} 
Model 3, the cost of the subsidies is 0.12 percent of payroll, while the combined cost of the progressive expansions is 0.21 .

\section{COMBINED EFFECT OF TRADITIONAL BENEFIT CHANGES AND INDIVIDUAL ACCOUNTS}

This section combines the changes described in Sections I and II to examine some overall impacts of the proposals. For this evaluation we need to use an assumption as to the fraction of workers who choose individual accounts. The Commission's Report analyzes the cases of twothirds participation and complete participation. With such a large subsidy, we think that full participation is the more plausible case under Model 2. With the need to provide a matching add-on account, two-thirds participation is more plausible for Model 3. We report results accordingly, with both cases generally in the Tables.

\section{A. Actuarial Balance}

As noted in Section I, the changes to traditional benefits restore actuarial balance in both Models 2 and 3 in the absence of individual accounts. As noted in Section II, the presence of individual accounts has a negative impact on actuarial balance. The Commission proposed addressing the financing problems associated with individual accounts by transferring general revenues to Social Security. In particular, the Commission proposed that transfers be large enough to prevent the Trust Fund balance from ever falling below 100 percent of expenditures. It is worth noting that the size of the resultant transfers reflects the financial difficulties created by individual accounts, since Social Security would be in actuarial balance under Model 2 without such accounts.

These transfers would be needed between 2021 and 2055 assuming 100 percent participation in the accounts. ${ }^{62}$ The present value of these general revenue cash transfers to

\footnotetext{
${ }^{62}$ The transfers occur between 2025 and 2054 assuming two-thirds participation.
} 
Social Security is 1.2 percent of payroll (Table 15). ${ }^{63}$ Thus the ultimate impact on Social Security's actuarial balance is a net cost of 1.1 percent of payroll associated with participation in individual accounts, combined with an injection of 1.2 percent of payroll from general revenue. The actuarial balance improves by 0.15 percent of payroll, but only because of the large general revenue infusions. The cost of these transfers is less than the cost of financing scheduled benefits out of general revenues, which would be 1.9 percent of payroll.

The results for Model 3 are similar (see Table 16). Transfers are needed between 2034 and 2065 with two-thirds participation. The individual accounts, including the diverted revenue and the offsets from the liability accounts, cause deterioration in the 75-year actuarial balance of 0.4 percent of payroll. The general revenue infusions triggered by the diversion of revenue into the accounts are substantial enough, however, to produce an apparent improvement in the actuarial balance as the participation rate increases. As with Model 2, this result obtains solely because of the infusion of general revenue. ${ }^{64}$ And as with Model 2, the cost of general revenues for the dedicated revenues (which do not have a recommended source) plus the transfers needed because of the individual accounts is less than the cost of financing scheduled benefits out of general revenues, which would be 1.9 percent of payroll. ${ }^{65}$

As noted above, preserving benefits in current law would require general revenues of 1.9 percent of payroll (given the 2001 assumptions used by the Commission), while Models 2 and 3 would require revenue equal to 0.8 and 1.1 percent of payroll respectively with two-thirds takeup (including the dedicated revenue under Model 3 and the subsidies for the contributions to the

\footnotetext{
${ }^{63}$ Amusingly, the Report states that "Model 2 establishes a voluntary personal account without raising taxes or requiring additional worker contributions." (See Strengthening Social Security and Creating Personal Wealth for All Americans, pages 15, 83, and 119.) Such a statement ignores the role of the transfers.

${ }^{64}$ The difference between the account yield actually earned on asset accounts and the Trust Fund interest rate has a small effect on Social Security solvency, since withdrawals from the individual accounts are treated for income tax purposes like Social Security benefits. Since the Social Security system is credited with part of the income taxation of Social Security benefits, it would also be credited with part of the income taxation of the individual account withdrawals. Therefore, since the expected individual account returns are higher than the Trust Fund returns (because the individual accounts are partially invested in equities) the expected income tax credited to the Trust Fund is increased. In effect, the Trust Fund recaptures a share of the difference between the account yield and the Trust Fund yield through the income taxation of benefits. This effect is quite modest, however, as explained in a footnote above.

${ }^{65}$ In addition to examining the present discounted value of transfers, the Commission Report presents figures that simply add real transfers over the 75-year horizon. We do not see any interesting question that this illuminates and do not report such figures.
} 
add-on accounts, but ignoring the contributions themselves). Model 2 with full take-up would require general revenues of 1.2 percent of taxable payroll (see Table 17). ${ }^{66}$

These figures assume significant reductions in disability and child survivor benefits; if those reductions did not occur, the required reductions in retirement benefits would be correspondingly larger (or the required general revenue transfers would be larger, as shown in Table 17). If general revenues were added that were sufficient to preserve the current level of disability benefits, this would cost roughly 0.3 percent of taxable payroll for Model 2, and 0.17 percent for Model 3. Adding these to the numbers above, we see that Models 2 and 3 would require revenue equal to 1.1 and 1.3 percent of payroll respectively with two-thirds take-up. Model 2 with full take-up would require general revenues of 1.5 percent of taxable payroll. This is still less than the 1.9 percent of payroll needed to finance currently scheduled benefits, but it is not vastly less.

\section{B. Social Security Trust Fund}

The actuarial effects described above are reflected in the evolution of the Social Security Trust Fund under the proposed plans. Under Models 2 and 3, for example, funding individual accounts involves a diversion of payroll tax revenues from the Social Security Trust Fund to individual accounts. The liability accounts associated with the payroll tax diversion then result in decreased benefit payments from the Trust Fund after some period. This pattern of changed cash flows, out of the Trust Fund early and into the Trust Fund later, alters the balance in the Trust Funds.

As with the 75-year actuarial analysis above, the effects on the Trust Fund depend on whether the general revenue transfers are included or excluded. We focus on the impact on the Trust Fund from the combination of the benefit reductions in Models 2 and 3 and the cash flow shortfalls caused by individual accounts, excluding the transfers from general revenue but

\footnotetext{
${ }^{66}$ Amusingly, the Report states that "Model 2 establishes a voluntary personal account without raising taxes or requiring additional worker contributions." (See Strengthening Social Security and Creating Personal Wealth for All Americans, pages 15, 83, and 119.) Such a statement ignores the role of the transfers.
} 
including the dedicated transfers that are part of Model 3. Below, this is compared to the Trust Fund with scheduled benefits, which also involves no such transfers.

Both models change the dates at which the cash flow first becomes negative and the dates at which the Trust Fund is exhausted if there are no further general revenue transfers. As shown in Table 18, without the general revenue infusions, the Trust Fund exhaustion date shifts from 2038 (under the 2001 baseline projections) to 2025 under Model 2 with full participation. The exhaustion date is pushed back to 2039 under Model 3 with two-thirds participation - but it is important to remember that this figure reflects the dedicated general revenue under the base component of Model 3.

\section{Debt Held by the Public}

Since the Trust Funds holds Treasury debt, a change in the balance in the Trust Funds implies a change in Treasury borrowing from the public, holding other government taxes and spending constant. ${ }^{67}$ Similarly, the decreases in traditional benefits that are part of Models 2 and 3 and that are described in Section I affect both the Trust Fund balances and Treasury borrowing from the public.

Another way to think about the cash flow implications is to examine the extent of Treasury borrowing from the public that would be necessary to pay the scheduled benefits in current law and in the Commission proposals. These sums are shown in Table 19. Adding two percent individual accounts to current law, as under Model 1, increases Treasury borrowing from the public by $\$ 443$ billion (in 2001 dollars) by $2010 .^{68}$ This sum reaches $\$ 1.3$ trillion by 2020 and $\$ 2.5$ trillion by 2030 , increasing steadily thereafter throughout the projection period. ${ }^{69}$

\footnotetext{
${ }^{67}$ In other words, the diversion of payroll revenue into individual accounts will affect the unified budget balance and therefore also affect debt held by the public, all else being equal.

${ }^{68}$ Holdings of bonds in individual accounts are considered part of borrowing from the public.

${ }^{69}$ This calculation assumes that this additional borrowing has no effect on the interest rates that the Treasury pays. One would expect such a large increase in borrowing to increase the interest rate that the Treasury has to pay, adding to the need to borrow.
} 
Since they include larger individual accounts, Models 2 and 3 start out with even larger sums needed to be borrowed from the public than with Model 1 (without considering the cost of subsidizing individual contributions in Model $3^{70}$ ): $\$ 802$ billion in 2010 for Model 2 with full participation; and $\$ 475$ billion for Model 3 with two-thirds participation. Because benefits are reduced in both Models 2 and 3, the amount of additional borrowing eventually falls below what would occur if borrowing were used to finance the scheduled benefits in current law.

\section{Monthly Benefits}

To consider the impact of the reform Models on retirees, we need to consider the benefits that can be financed by the individual accounts along with the reduction in traditional benefits. We focus on the case where all the assets in the accounts are used to purchase annuities that are constant in real terms, as are traditional benefits. ${ }^{71}$ We focus on Models 2 and 3 and begin with the results for 65-year-old two-earner couples.

We initially focus on the expected benefits assuming a net real rate of return (after administrative costs) on the individual account balances of 4.6 percent. (This figure assumes administrative costs of 30 basis points, even though we argued that the administrative costs were too low if Tier II were much used or a serious attempt was made -- using financing from individual accounts -- to educate the public about investments. A higher administrative cost figure would reduce the net return.) After discussing expected benefits, we consider riskadjusted benefits.

We consider two workers in detail, along with some summary figures on a variety of cohorts. The two workers we consider in detail are those who first have a full career under the new system and those who are the last to have a full career within the 75 -year projection period. The former corresponds to those who become eligible for retirement benefits at age 62 in 2049 (and are therefore just beginning their careers when the changes to traditional benefits are made

\footnotetext{
${ }^{70}$ Since the Commission did not recommend increasing the maximal earnings subject to tax, we evaluate Model 3 with all of "dedicated revenues" coming from increased borrowing.
} 
in 2009). The latter corresponds to those who become eligible for retirement benefits at age 62 in 2072, and are therefore 65 in 2075.

Under the 4.6 percent real net return assumption, as Table 20 illustrates, a mediumearning two-earner couple claiming benefits at age 65 in 2052 would each receive an expected combined benefit under Model 2 -- including the annuity from the individual account -- that is 6 percent below scheduled benefit levels. Note that if such a couple were not to participate in the individual account system, the reduction would amount to 33 percent. The difference between the 33 percent and 6 percent reductions reflect two factors: the subsidy to the individual account from having an interest rate on the liability accounts below the Trust Fund interest rate, and the higher expected return on stocks than on the Treasury bonds held by the Trust Fund (the equity premium). ${ }^{72}$ As discussed further below, this apparent gain does not take account of the financial risks associated with equities.

A high-earning couple participating in the individual accounts would experience a somewhat larger percentage reduction in combined expected benefits than the medium earners, because the individual account contribution limit of $\$ 1,000$ (indexed) means that a smaller percentage of future benefits would be replaced by the individual account for such higher earners. A lower-earning couple would actually experience an increase in combined benefits relative to scheduled benefit levels, mostly because of the benefit increase for lower earners.

Under Model 3, the combined benefits (including the retirement income from the additional one percent add-on contributions) are somewhat above scheduled benefits. Without the additional one percent contribution, however, the combined benefit levels would be very slightly below scheduled levels for the lower-earning couple, 5 percent below for the mediumearning couple, and 7 percent below for the higher-earning couple (see the bottom row of Table 20).

\footnotetext{
${ }^{71}$ If all of the funds in individual accounts are used for annuitized benefits, none are left for bequests. It is important to underscore that the sums in individual accounts are either available to finance annuitized benefits or are wealth that can be bequeathed, but not both (or a mix of the two uses).

${ }^{72}$ These two factors more than explain the difference between the expected benefit from not participating in the accounts and the expected combined benefit (without risk adjustment) conditional on participation, since
} 
Table 21 presents the combined benefit figures for two-earner couples claiming benefits at age 65 in 2075. The same basic patterns emerge as with the earlier cohort, except that the impact of the shift to price-indexing under Model 2 has had more time to compound and so has a more pronounced effect. The lower-earner couple under Model 2, for example, now has expected combined benefits below scheduled levels.

Tables 22 and 23 present the expected combined benefit figures for the same cohorts of workers, but assuming they claim benefits at age 62 (in 2049 and 2072 respectively). For Model 2 , the pattern is similar to that when claiming benefits at age 65 , with only marginally larger percentage reductions in expected combined benefits relative to scheduled benefits at age 62 . For Model 3, the percentage reductions in expected combined benefits relative to scheduled benefits are significantly larger at age 62 than at age 65 , reflecting the adjustments made under Model 3 to the early reduction factors.

Tables 24 to 27 present the results for one-earner couples. The expected combined benefit reductions are more substantial for such couples, primarily because Social Security provides a subsidy to one-earning couples whereas individual accounts do not. For one-earner couples claiming benefits at age 62 in 2049, the combined benefit reductions under Models 2 or 3 would range from 3 percent to 19 percent relative to scheduled benefits (Table 26). For oneearner couples claiming benefits at age 62 in 2072, the combined benefit reductions under Models 2 or 3 would range from 17 percent to 33 percent relative to scheduled benefits (Table 27).

Tables 20 through 27 present the expected combined benefit reductions (relative to scheduled benefits) for those who choose not to participate in the individual accounts and for those who choose to do so. For a medium-earning two-earner couple claiming benefits at age 62 in 2072, for example, the benefit reduction under Model 2 amounts to 46 percent if the individual account option were not chosen, and to 23 percent if the couple opted for an account. That

participation also involves administrative costs. In other words, the risk-adjusted expected combined benefit for participants is below the expected traditional benefit for non-participants. 
calculated improvement reflects two components: the subsidy to the individual account and the use of expected returns rather than adjusting equity returns for their risk. We now turn to analyzing each of these components.

Table 28 shows the contribution of the subsidy to the individual account in explaining the tabulated improvement from participating in the individual account. In particular, if the rate used for liability accounts under Model 2 were 3 percent rather than 2 percent (so that the individual accounts were not subsidized apart from the implicit life insurance), the combined benefit if the couple claiming benefits in 2072 had opted for an account would be 32 percent below scheduled levels (rather than 23 percent with the 2 percent rate). Thus, of the 23 percent of scheduled benefit increase associated with participating in the accounts relative to not participating, roughly half (about 10 percent of scheduled benefits) is due to the subsidy and the rest is due to the equity premium. (As noted in a footnote above, administrative costs mean that these two effects sum to more than the difference between the traditional benefit level for non-participants and the expected combined benefit level for those who do participate in the accounts.) The subsidies play a smaller role under Model 3, as the bottom part of Table 28 demonstrates, since the rate on liability accounts is higher.

Tables 20 through 27 also do not adjust for the risk inherent in the individual account portfolios. $^{73}$ To do so, we follow the memo of the actuary and report benefit financing using three different rate of return assumptions. One alternative calculation is based on a higher rate of return, as would occur with a portfolio that was 60 percent in stocks rather than 50 percent. A final alternative is based on a portfolio that is completely invested in government bonds, which can also be interpreted as a risk adjustment assuming indifference between the different assets in

\footnotetext{
${ }^{73}$ For further discussion of risk in the context of individual accounts, see Max Alier and Dmitri Vittas, "Personal Pension Plans and Stock Market Volatility," in R. Holzmann and J. Stiglitz, eds., New Ideas about Old Age Security (The World Bank: Washington, 2001); Gary Burtless, "Asset accumulation and retirement income under individual retirement accounts: Evidence from five countries," Paper prepared for the Third International Forum of the Collaboration Projects on Aging Issues, Economic and Social Research Institute, September 17-19, 2001, Tokyo, Japan; Burtless, "Social security privatization and financial market risk: Lessons from U.S. financial history" in T. Ihori and T. Tachibanaki, eds., Social Security Reform in Advanced Countries (Routledge: London and New York, forthcoming); John Geanakoplos, Olivia S. Mitchell, and Stephen P. Zeldes, "Would a privatized social security system really pay a higher rate of return?' in R. D. Arnold, M. Graetz, and A. Munnell, eds., Framing the Social Security Debate: Values, Politics and Economics (National Academy of Social Insurance: Washington, 1998); and Kevin Murphy and Finis Welch, "Perspectives on the social security crisis and proposed solutions," American Economic Review 88(2), 1998.
} 
portfolios. ${ }^{74}$ This is plausibly an upper bound on the extent of a risk adjustment since equality of valuation of assets holds for those with outside assets, who can thus adjust their overall portfolios. For those who would hold stocks out of wealth but have no wealth outside Social Security, there is a utility gain. Some others may be sufficiently risk averse to prefer an all-bond portfolio and can choose to do so. ${ }^{75}$

As above, we look at two cohorts in detail, followed by a summary table on successive cohorts. The two cohorts we consider in detail are the first cohort fully under the new system (age 21 in 2008 and therefore age 62 in 2049) and one of the last cohorts within the 75 year horizon (age 65 in 2075).

As Table 29 shows, the risk-adjusted results for the medium-earning two-earner couple produce a combined benefit reduction relative to scheduled benefits of 26 percent under Model 2 and 10 percent under Model 3. In particular, the "full" risk adjustment - reflected in the use of the Treasury yield rather than the equity yield, and therefore the assumption that the entire equity premium is compensation for risk - amounts to about 20 percent of scheduled benefits under both Model 2 and Model 3 (compare the "low yield" to "50-50 equity-bond yield" cases in Table 26). Under the high yield scenario, the combined benefit reductions are mitigated under Model 2, and the expected benefit gain is somewhat larger under Model 3. Table 30 presents the results for the medium-earning two-earner couple claiming benefits at age 65 in 2075.

\footnotetext{
${ }^{74}$ Indeed, in evaluating the recent legislation to allow the Railroad Retirement Fund to invest in equities, both the Congressional Budget Office (CBO) and the Administration itself argued that stock investments should be "scored" using the government bond yield. As the Administration argued, "Equities and private bonds earn a higher return on average than the Treasury rate, but that return is subject to greater uncertainty...Economic theory suggests, however, that the difference between the expected return of a risky liquid asset and the Treasury rate is equal to the cost of the asset's additional risk as priced by the market. Following through on this insight, the best way to project the rate of return on the Fund's balances is to use a Treasury rate." Office of Management and Budget, Budget Systems and Concepts, Fiscal Year 2003, pages 15-16.

${ }^{75}$ On risk aversion and social security portfolios, see Peter Diamond and John Geanakoplos, "Social Security Investment in Equities I: Linear Case," (with J. Geanakoplos), National Bureau of Economic Research Working Paper No. 7103, April 1999. Revised version, Cowles Foundation Discussion Paper, 2001 and John Geanakoplos, Olivia S. Mitchell, and Stephen P. Zeldes, "Would a privatized social security system really pay a higher rate of return?' in R. D. Arnold, M. Graetz, and A. Munnell, eds., Framing the Social Security Debate: Values, Politics and Economics (National Academy of Social Insurance: Washington, 1998).
} 
Table 31 presents the combined benefit levels, relative to scheduled benefits, under Models 2 and 3 for medium-earning couples of different cohorts claiming benefits at age 65 . It shows the pattern of combined benefits over time for two-earner couples and one-earner couples, and with and without adjusting for risk. As the table indicates, the risk-adjusted combined benefit levels fall over time relative to scheduled benefits; are lower under Model 2 than Model 3 (the Model 3 results, it should be remembered, include the additional one percent contributions); and are lower for one-earner couples than two-earner couples.

In considering the various comparisons in Tables 19 through 31, two points are worth noting. First, the figures assume that account balances at retirement are transformed into immediate life annuities. That means that, despite the rhetoric of the Commission regarding bequests, implicit in this comparison is that no funds would be left to heirs following retirement. To the extent that the annuities involved provisions that might provide funds for heirs, retirement income would be correspondingly lower. In particular, each dollar that a pensioner bequeaths to heirs means a dollar less spent to support retirement expenditures. ${ }^{76}$

Second, as noted above, these Models involve lower levels of general revenue financing of benefits than does current law, requiring consideration of costs as well as benefits. Below we consider benefits under two alternative baselines that cost the same as Model 2.

\section{Individual Account Assets}

In addition to the implications for the trust fund, the debt held by the public, and the individual liability accounts, the Models also imply a significant buildup of assets in the

\footnotetext{
${ }^{76}$ The assumption of immediate life annuities without any guarantee period is inconsistent with the behavior of the majority of annuitants in both the United States and the United Kingdom. Providing a guaranteed period during which the annuity would be paid to a survivor (other than the spouse) would reduce income during retirement. It is also worth noting, as the actuaries do on page 31 of their analysis, that the annuity estimates may be overstated because they assume that the aggregate mortality rates are weighted by people rather than account balances. As the actuaries note, "personal account annuities and benefit offset amounts may tend to be somewhat overstated. Mortality for the individual account annuities calculated here is assumed to be the average for the total U.S. population, for all income levels. In fact, the expected mortality experience of annuitants, weighted by amount of assets to be annuitized, would be better (lower death rates) than for the general population. Individuals with lower accumulated assets due to lower lifetime earnings, or disability prior to retirement, tend to have higher mortality, all else being equal. Thus, the use of general-population mortality in these illustrations tends to understate the weighted life expectancy of annuitants, and overstate the size of the monthly annuity from individual account accumulations."
} 
individual accounts. In Table 32, we show account values relative to GDP. Under Model 2 with full participation, balances are over 50 percent of GDP by 2075. Under Model 3 with two-thirds participation, balances are 44 percent of GDP by 2075.

We do not attempt to connect all of the changes above to changes in national savings, which would be complex. Such analysis would have to examine the response of private savings and government taxes and spending to the changes in benefits, the buildups in the accounts, and the transfers of general revenues. ${ }^{77}$

\section{E. Comparison to Additional Baselines}

We have compared both costs and benefits under Models 2 and 3 with the baseline of scheduled benefits. This comparison combines issues of different levels of financing with different patterns of effects on different cohorts. To help separate these issues, we now compare Model 2 with two alternative baselines that are constructed to reach 75-year balance with the same amount of general revenue transfers as Model 2, adjusted for protection of the disabled. The alternative baselines accomplish this by simply reducing traditional retirement benefits to eliminate the 75-year imbalance remaining after the transfers. (These alternatives are described for comparative purposes only; they do not represent a reform plan that we favor.)

In particular, if the disabled are held harmless from the benefit reductions under Model 2 and all eligible workers participate in the individual accounts, general revenue transfers equal to 1.53 percent of payroll. Under the alternative plans, the actuarial deficit remaining after the transfers would therefore be 0.33 percent of payroll (the 1.86 percent of payroll deficit under the 2001 Trustees assumptions used to evaluate the Commission plans, minus the 1.53 percent of payroll in transfers). To make the alternatives as comparable as possible to Model 2, the alternatives are also assumed to include benefit expansions for low-benefit widows and widowers, and for low earners with long careers. Rather than designing specific expansions, we include a cost equal to that of the similar two provisions included in Model $2-0.21$ percent of

\footnotetext{
${ }^{77}$ For a preliminary analysis of that topic, see Barry Bosworth and Gary Burtless, "Economic and Distributional Effects of the Proposals of President Bush's Social Security Commission," Center for Retirement Research, May 20, 2002 .
} 
payroll, raising the actuarial deficit after these provisions are included to 0.54 percent of payroll. $^{78}$

The alternative plans therefore need to reduce benefits by 0.54 percent of payroll to achieve 75-year solvency. Both alternatives maintain disability benefits (and benefits for current retirees and near retirees) at their levels under the current benefit formula. They differ in how they would phase in the required benefit reductions for other beneficiaries. The first alternative plan would phase in the required benefit reductions over the 75-year period in the same way as the traditional benefit reductions are phased in under Model 2. In other words, for each generation, the benefit reductions under the alternative are a fraction of the traditional benefit reductions under Model 2, with the fraction equal to $(0.54) /(2.07-0.30)$, where 0.54 is the actuarial imbalance remaining after the transfers and the low-earner/survivor provisions, and (2.07-0.30) is the impact of the price indexing proposal under Model 2 on the non-disabled. The implication is that, for every cohort of workers, the benefit reduction under the alternative is 31 percent of the reduction under the price-indexing component of Model 2.

The second alternative plan would simply reduce benefits by the same percentage for all new retirees after 2009 , rather than allowing that percentage to increase over time as under the other alternative. In particular, according to calculations in Aaron and Reischauer (2001) and Aaron, Blinder, Munnell, and Orszag (2000), the present value of benefits to be paid to current retirees, those 55 and over in 2002 (who become eligible for benefits before 2009), and the disabled (prior to conversion to retirement benefits at the normal retirement age) amounts to 6.2 percent of payroll. ${ }^{79}$ Taking total projected benefits of 15.4 percent of payroll and subtracting the 6.2 percent for "protected" benefits leaves 9.2 percent of payroll for new retirees who become eligible for benefits in 2009 or thereafter. The percentage reduction in benefits required to eliminate the actuarial imbalance is therefore $0.54 / 9.2$, or 5.9 percent.

\footnotetext{
${ }^{78}$ Because of interactions among the provisions, the precise cost of the provisions under the alternative plans may differ slightly from the 0.21 percent of payroll estimate for the provisions from Model 2 . We adopt the 0.21 percent estimate for simplicity.

${ }^{79}$ See Henry J. Aaron and Robert D. Reischauer, Countdown to Reform: The Great Social Security Debate, Revised and Updated for 2001 (Century Foundation: New York, 2001), page 147; and Henry J. Aaron, Alan S. Blinder, Alicia H. Munnell, and Peter R. Orszag, "Governor Bush's Individual Account Proposal," The Century Foundation, Issue Brief Number 11, June 2000. It should be noted that these figures were based on the 2000 Trustees Report assumptions, not the 2001 Trustees Report assumptions upon which the Commission plans were evaluated.
} 
Table 33 compares the benefit reductions under these alternative plans to the benefit reductions under Model 2 for different generations of medium-earning two-earner couples that claim benefits at age 65 . As the table shows, such a couple retiring in 2032 would experience an 18.2 percent reduction in benefits under Model 2 if it did not participate in the individual accounts. If it did participate in the accounts, its expected combined benefits (adjusted for risk) would be 15.2 percent below scheduled benefit levels. The first alternative plan, by contrast, would require a 5.5 percent benefit reduction for such a couple. The second alternative would require a 5.9 percent benefit reduction. By 2075, Model 2 would involve a 40 percent reduction in expected combined benefits (adjusted for risk) for the couple if it participated in the individual accounts, whereas the alternatives would involve reductions of between 5.9 and 14.0 percent.

The reason for the generally larger expected benefit reductions under Model 2 than the alternatives is that Model 2 would leave the Social Security system in a stronger financial position at the end of the 75-year period. Under Model 2, but not under the alternatives, the system would remain in balance after 2076. (Another reflection of Social Security's fiscal position after 75 years is that the value to the Social Security system of the accumulated amounts in the liability accounts, which reduce later benefits, would amount to more than 20 percent of GDP at the end of the 75-year period. ${ }^{80}$ ) For a given level of transfers and adjusting for risk, the fundamental tradeoff between the approach in Model 2 and the alternative approach of reducing benefits sufficiently to reach balance over the next 75 years thus is that Model 2 would produce lower expected benefits over the next 75 years, but leave Social Security in a stronger financial position at the end of the 75-year period. The same general point holds with regard to Model 3.

\footnotetext{
${ }^{80}$ The value to Social Security of the balances in liability accounts is adjusted for the lower interest rate charged on these accounts, as described in the note to Table 16.
} 


\section{Conclusion}

In this final section, we summarize several of the crucial issues with which the Commission decided not to grapple.

The first issue involves benefits for the disabled and surviving young children. As noted above, the Commission apparently does not support the dramatic implications of its proposals for disability benefits. The logic of offsetting traditional benefit reductions by income from an individual account is not applicable to disability beneficiaries, who would not be allowed access to their individual accounts prior to retirement but would still suffer substantial traditional benefit reductions. Nevertheless, the Commission still counts every penny of decreased disability benefits in its actuarial scoring. While the Commission was willing to assume substantial general revenue infusions to subsidize individual accounts, it was unwilling to use general revenue or other means to protect the disabled and young survivors from the traditional benefit reductions called for under Models 2 and 3.

A second issue involves risk. The Report repeatedly mentions the increase in the expected return from holding a diversified portfolio, but we failed to notice a single mention of the increased risk associated with a diversified portfolio, except in the memo from the actuary. The Report also eschews the use of "risk adjustment" of returns to account for the impact on investors, despite the Administration's own embrace of full risk adjustment when evaluating stock investments by the Railroad Retirement Board. ${ }^{81}$ To the extent that the higher expected returns from equities merely reflect their risk, many of the figures touted by the Report are readily misinterpreted.

A related issue involves "political risk." To be sure, not restoring long-term actuarial balance within Social Security leaves current workers more uncertain about the future evolution of taxes and benefits than if there were actuarial balance. Such uncertainty includes an element

\footnotetext{
${ }^{81}$ See the discussion in Office of Management and Budget, Budget Systems and Concepts, Fiscal Year 2003.
} 
of political risk. Legislating a credible plan that restores actuarial balance would help to reduce this source of risk. ${ }^{82}$

"Political risk" is more subtle with regard to an actuarially balanced system. In particular, given actuarial balance, it is not clear whether the possibility of further legislation should be viewed as a political risk or a political hedge. The possibility of adapting Social Security to changing economic and demographic circumstances makes it more valuable to society, not less valuable. (In other words, it would be wrong to view any possibility to adapt the system as a risk with a negative connotation.) It is therefore important to distinguish legislated changes that respond merely to shifts in political circumstances from changes that result from shifts in the underlying economic or demographic circumstances. Only the former truly represents political risk. ${ }^{83}$

Several elements of the Commission's reform models seem to us sources of political risk under this definition: that is, candidates for potential legislative changes purely as a consequence of an evolution in political attitudes. Examples include the restrictions on account portfolios and on access to accounts before retirement under the Commission plans; such provisions might not be viable in the long run as the politics of Social Security evolve. Given the rhetoric that the accounts belong to the worker, these government restrictions may be increasingly viewed as a form of interference with property rights, rather than a form of government-provided protection.

A final issue involves the budget outlook. Since actuarial imbalance involves political risk, a claim of actuarial balance that is substantially dependent on general revenue transfers in the current budgetary context does so also. Without any other reforms, Congress could legislate that the Trust Fund would be able to draw upon general revenue whenever necessary to finance scheduled benefits. Such legislation would eliminate the measured actuarial imbalance. (This

\footnotetext{
${ }^{82}$ For discussions of political risk, see Hugh Heclo, "A Political Science Perspective on Social Security Reform," in R. Douglas Arnold, Michael J. Graetz, and Alicia H. Munnell, Framing the Social Security Debate: Values, Politics, and Economics (National Academy of Social Insurance: 1998) and Diamond, 1999, op. cit.

${ }^{83}$ If changes to the program's structure in response to economic and demographic shifts were nonetheless classified as "political" risk, the liability accounts created by the Commission proposals would appear to be exposed to such risk - perhaps as much, and potentially even more so, than the current defined benefit system. Consider, for example, the pressure that could result to raise the interest rate charged on liabilities if, for some reason, equity
} 
legislated ability to draw on general revenues would not be needed until 2041 under the latest projection.) However, without any other budget changes, such legislation would not eliminate political risk since there would be no confidence that the general revenue transfers would occur when the budgetary need arrived.

Similarly, all three Commission reform models involve significant transfers of general revenues to Social Security for sustained periods without Commission recommendations of any other changes in the Federal budget to finance the transfers. ${ }^{84}$ Table 17 presents the figures: The general revenue transfers assuming universal participation in the accounts amount to between 1.2 and 1.7 percent of payroll (depending on the Model and whether the disabled would be held harmless from the benefit reductions). With the current budget outlook, ${ }^{85}$ simply assuming the availability of such large transfers is problematic.

Indeed, reliance on such transfers creates the very real possibility that the assumed level of funding will not materialize. To the extent that the assumed funding does not turn out to be available, benefits may well be reduced as part of adapting the system to the level of available funds. In the absence of a significant shift in the budget outlook, such a scenario seems a very real political risk -- despite the fact that recently the Co-Chairs of the Commission have denied this as a possibility: "Any attempt to draw a connection between the adoption of personal accounts leading to reductions of seniors' current benefits is wholly without foundation." ${ }^{.86}$ In our view, introducing personal accounts and so requiring large transfers to Social Security (as shown in Tables 15, 16, and 17) without making room for such transfers in the rest of the Federal budget does indeed put the benefits of seniors at risk.

returns proved to be surprisingly high while fertility rates declined more rapidly than had been expected. Or consider the pressure to lower the interest rate charged if equity returns have been low.

${ }^{84}$ Under Model 2 with two-thirds take-up, the transfers occur from 2025 to 2054, and amount to 3.6 percent of taxable payroll in 2026; with full take-up, the transfers occur from 2021 to 2055 and reach more than 4 percent of taxable payroll at their peak. Under Model 3 with two-thirds take-up, general revenue transfers (in addition to the dedicated revenues) occur from 2034 to 2065 , and amount to 2.5 percent of taxable payroll in 2035.

${ }^{85}$ For analysis of the budget outlook, see Congressional Budget Office, The Long-Term Budget Outlook, October 2000; General Accounting Office, "Long-Term Fiscal Issues," GAO-02-467T, February 27, 2002; and Alan J. Auerbach, William G. Gale, and Peter R. Orszag, "The Budget Outlook and Options for Fiscal Policy," The Brookings Institution, April 2002.

${ }^{86}$ Statement by the Co-Chairs of the President's Commission to Strengthen Social Security, May 7, 2002. 


\section{REFERENCES}

Henry J. Aaron and Robert D. Reischauer, Countdown to Reform: The Great Social Security Debate, Revised and Updated for 2001 (Century Foundation: New York, 2001)

Henry J. Aaron, Alan S. Blinder, Alicia H. Munnell, and Peter R. Orszag, "Governor Bush's Individual Account Proposal," The Century Foundation, Issue Brief Number 11, June 2000

Max Alier and Dmitri Vittas, "Personal Pension Plans and Stock Market Volatility," in R. Holzmann and J. Stiglitz, eds., New Ideas about Old Age Security (The World Bank:

Washington, 2001)

Alan J. Auerbach, William G. Gale, and Peter R. Orszag, "The Budget Outlook and Options for Fiscal Policy," The Brookings Institution, April 2002

Advisory Council on Social Security, Report of the 1994-1996 Advisory Council on Social Security, Volume I: Findings and Recommendations (Washington, D.C.)

Patrick Bayer, B. Douglas Bernheim, and John Karl Scholz, "The effects of financial education in the workplace: Evidence from a survey of employers," NBER Working Paper 5655, 1996

Barry Bosworth and Gary Burtless, "Economic and Distributional Effects of the Proposals of President Bush's Social Security Commission," Center for Retirement Research, May 20, 2002

Richard Burkhauser and Timothy Smeeding, "Social Security Reform: A Budget-Neutral Approach to Older Women's Disproportionate Risk of Poverty," Center for Policy Research, Maxwell School, Syracuse University, 1994

Gary Burtless, "Asset accumulation and retirement income under individual retirement accounts: Evidence from five countries," Paper prepared for the Third International Forum of the Collaboration Projects on Aging Issues, Economic and Social Research Institute, September 1719, 2001, Tokyo, Japan

, "Social security privatization and financial market risk: Lessons from U.S. financial history" in T. Ihori and T. Tachibanaki, eds., Social Security Reform in Advanced Countries (Routledge: London and New York, forthcoming)

Committee on Ways and Means, 2000 Green Book (Government Printing Office: Washington, 2000)

Congressional Budget Office, The Long-Term Budget Outlook, October 2000

Constance F. Citro and Robert T. Michael, ed., Measuring Poverty: A New Approach (National Academy Press: 1995)

Courtney Coile, Peter Diamond, Jonathan Gruber, and Alain Jousten, "Delays in Claiming Social Security Benefits," NBER Working Paper W7318, August 1999 
Peter A. Diamond, "What Stock Market Returns to Expect for the Future?" Social Security Bulletin, 2000

, "Administrative Costs and Equilibrium Charges with Individual Accounts," in John Shoven (ed.), Administrative Costs and Social Security Privatization, (University of Chicago Press: Chicago, 2000)

, and John Geanakoplos, "Social Security Investment in Equities I: Linear Case," (with J. Geanakoplos), National Bureau of Economic Research Working Paper No. 7103, April 1999. Revised version, Cowles Foundation Discussion Paper, 2001.

Douglas W. Elmendorf, Jeffrey B. Liebman, and David W. Wilcox, "Fiscal Policy and Social Security Policy During the 1990s," in Jeffrey A. Frankel and Peter R. Orszag, eds., American Economic Policy in the 1990s (MIT Press: 2002).

Melissa M. Favreault, Frank J. Sammartino, and C. Eugene Steuerle, "Social Security Benefits for Spouses and Survivors," in Melissa M. Favreault, Frank J. Sammartino, and C. Eugene Steuerle, eds., Social Security and the Family (Urban Institute Press: 2002)

John Geanakoplos, Olivia S. Mitchell, and Stephen P. Zeldes, "Would a privatized social security system really pay a higher rate of return?' in R. D. Arnold, M. Graetz, and A. Munnell, eds., Framing the Social Security Debate: Values, Politics and Economics (National Academy of Social Insurance: Washington, 1998).

General Accounting Office, "Long-Term Fiscal Issues,” GAO-02-467T, February 27, 2002

Stephen C. Goss, "Long-Range OASDI Financial Effects of a Proposal to CPI-Index Benefits Across Generations," Office of the Chief Actuary, Social Security Administration, May 3, 1999

Alan Greenspan, "Saving for Retirement," Remarks before the 2002 National Summit on Retirement Savings, the Department of Labor, Washington, D.C., February 28, 2002

Jonathan Gruber and Peter Orszag, "What To Do About the Social Security Earnings Test," Issue in Brief Number 1, Center for Retirement Research, Boston College, July 1999

Hugh Heclo, "A Political Science Perspective on Social Security Reform," in R. Douglas Arnold, Michael J. Graetz, and Alicia H. Munnell, Framing the Social Security Debate: Values, Politics, and Economics (National Academy of Social Insurance: 1998)

Karen Holden and Cathleen Zick, "Insuring against the Consequences of Widowhood in a Reformed Social Security System," in R. Douglas Arnold, Michael J. Graetz, and Alicia H. Munnell, Framing the Social Security Debate: Values, Politics, and Economics (National Academy of Social Insurance: 1998) 
Arthur Levitt, "The SEC Perspective on Investing Social Security in the Stock Market," John F. Kennedy School of Government, Harvard University, October 19, 1998

Kevin Murphy and Finis Welch, "Perspectives on the social security crisis and proposed solutions," American Economic Review 88(2), 1998

Mamta Murthi, J. Michael Orszag, and Peter R. Orszag, "Administrative Costs under a Decentralized Approach to Individual Accounts: Lessons from the United Kingdom," in R. Holzmann and J. Stiglitz, eds., New Ideas About Old Age Security (The World Bank: 2001)

Orlo R. Nichols, Michael D. Clingman, and Milton P. Glanz, "Internal Real Rates Of Return Under The OASDI Program For Hypothetical Workers," Actuarial Note Number 144, Office of the Chief Actuary, Social Security Administration, June 2001

Office of Management and Budget, Budget Systems and Concepts, Fiscal Year 2003

(Washington, D.C.)

Office of Policy, Office of Research, Evaluation, and Statistics, Social Security Administration, "Earnings of Black and Nonblack Workers: Who Died or Became Disabled in 1996 and 1997?" Note No. 2000-01, November 2000

Panel on Privatization of Social Security, Issues in Privatization of Social Security, Report of the Panel on Privatization of Social Security (MIT Press: Cambridge, 1999)

President's Commission to Strengthen Social Security, Strengthening Social Security and Creating Personal Wealth for All Americans (March 2002)

Virginia Reno, Jerry Mashaw, and Bill Gradison, eds., Disability: Challenges for Social Insurance, Health Care Financing, and Labor Market Policy (National Academy of Social Insurance: 1997)

Social Security Advisory Board, Estimating the Real Rate of Return on Stocks Over the Long Term, Washington, DC, August 2001.

Social Security Administration, 2002 Annual Report of the Board of Trustees of the Federal OldAge and Survivors Insurance and Disability Insurance Trust Funds

Statement by the Co-Chairs of the President's Commission to Strengthen Social Security, May 7 , 2002.

U.S. Department of the Treasury, Report of the Department of the Treasury on Employer Stock in 401(k) Plans, February 28, 2002

David Weaver, "The Widow(er)'s Limit Provision of Social Security," Social Security Bulletin, Vol. 64, No. 1, 2001/2002 


\section{Box 1}

The President's Commission to Strengthen Social Security was asked to make recommendations to modernize and restore fiscal soundness to Social Security, using six guiding principles:

- Modernization must not change Social Security benefits for retirees or near- retirees.

- The entire Social Security surplus must be dedicated only to Social Security.

- Social Security payroll taxes must not be increased.

- The government must not invest Social Security funds in the stock market.

- Modernization must preserve Social Security's disability and survivors insurance programs.

- Modernization must include individually controlled, voluntary personal retirement accounts, which will augment Social Security.

Source: The President's Commission to Strengthen Social Security/Guidelines 
Table 1: Model 2 Retirement Benefit Reductions from Shift to Price Indexation Relative to Scheduled Benefits in Current Law

\begin{tabular}{|l|c|}
\hline Age in 2002 & $\begin{array}{c}\text { Projected Percentage Retirement Benefit Reduction } \\
\text { from Shift to Price Indexation } \\
\text { (Relative to Scheduled Benefits in Current Law) }\end{array}$ \\
\hline 55 & 0 \\
\hline 50 & 4.5 \\
\hline 45 & 9.0 \\
\hline 40 & 13.3 \\
\hline 35 & 17.4 \\
\hline 30 & 21.2 \\
\hline 25 & 25.0 \\
\hline 15 & 28.5 \\
\hline 10 & 31.8 \\
\hline 5 & 35.1 \\
\hline 0 & 38.1 \\
\hline-5 & 41.0 \\
\hline-10 & 43.8 \\
\hline
\end{tabular}

Note: The benefit reduction is approximately equal to $1-\left(0.99^{55-\text { age }}\right)$, since the ultimate assumed real wage growth rate is 1 percent per year.

Source: Authors' calculations based on 2001 Trustees Report

Table 2: Model 2 Disability Benefit Reductions from Shift to Price Indexation Relative to Scheduled Benefits in Current Law

\begin{tabular}{|l|c|}
\hline Year of entitlement to disability & $\begin{array}{r}\text { Projected Percentage Disability Benefit Reduction from } \\
\text { Shift to Price Indexation } \\
\text { (Relative to Scheduled Benefits in Current Law) }\end{array}$ \\
\hline 2010 & 1.8 \\
\hline 2020 & 10.7 \\
\hline 2030 & 18.9 \\
\hline 2040 & 26.4 \\
\hline 2050 & 33.1 \\
\hline 2070 & 39.3 \\
\hline 2075 & 44.9 \\
\hline
\end{tabular}

Source: Authors' calculations based on 2001 Trustees Report 
Table 3: Effect of Model 2 Long-Career Low-Earner Provision Relative to the CPI-Indexed PIA

\begin{tabular}{|l|l|l|l|l|c|}
\hline & \multicolumn{4}{|l|}{$\begin{array}{l}\text { Ultimate Percentage Increase in Primary Insurance Amount (PIA) }{ }^{1} \text { for Retirees } \\
\text { with No Period of Disability (Increase is Relative to the CPI-Indexed PIA, } \\
\text { Starting in 2009) }\end{array}$} \\
\hline & Average earnings level (2002 wage levels) for years worked \\
\hline $\begin{array}{l}\text { Number of } \\
\text { years of work }\end{array}$ & $\$ 5,000$ & $\begin{array}{c}\$ 11,318 \\
\text { (minimum } \\
\text { wage) }\end{array}$ & $\begin{array}{c}\$ 15,875 \\
\text { scaled lower } \\
\text { earner) }\end{array}$ & $\begin{array}{c}\text { \$22,635 } \\
\text { (twice } \\
\text { minimum } \\
\text { wage) }\end{array}$ & $\begin{array}{c}\$ 35,277 \\
\text { (scaled } \\
\text { medium } \\
\text { earner) }\end{array}$ \\
\hline 10 & 0 & 0 & 0 & 0 & 0 \\
\hline 20 & 0 & 0 & 0 & 0 & 0 \\
\hline 30 & 40 & 40 & 28 & 10 & 0 \\
\hline 40 & 40 & 35 & 21 & 0 & 0 \\
\hline
\end{tabular}

${ }^{1}$ Ultimate increase is phased in over 10 years, 2009-2018. For workers with a given AIME, the increase is the same for 30 or more years of work. Increase reduced to 0 for 20 years of work or less. Based on intermediate assumptions of the 2001 Trustees Report.

Source: Memorandum from the Office of the Chief Actuary, page 5.

Table 4: Actuarial Balance for Model 2 without Personal Accounts

\begin{tabular}{|l|c|}
\hline & Percent of Payroll \\
\hline Current Law & -1.86 \\
\hline Change to price indexing for those under 55 & +2.07 \\
\hline Increased minimum benefit & -.13 \\
\hline Increased widow(er) benefit & -.08 \\
\hline Balance & +.01 \\
\hline
\end{tabular}

Source: Memorandum from the Office of the Chief Actuary, pages 4-6. 
Table 5: Model 3 Retirement Benefit Reductions From Life Expectancy Adjustment, Relative to Scheduled Benefits, for Retired Worker Claiming Benefits at Normal Retirement Age

\begin{tabular}{|l|c|}
\hline Age in 2002 & $\begin{array}{c}\text { Projected Percentage Retirement Benefit Reduction from Life } \\
\text { Expectancy Adjustment, Assuming Benefits Claimed at Normal } \\
\text { Retirement Age } \\
\text { (Relative to Scheduled Benefits in Current Law) }\end{array}$ \\
\hline 55 & 0.0 \\
\hline 50 & 2.5 \\
\hline 45 & 4.9 \\
\hline 40 & 7.2 \\
\hline 35 & 9.5 \\
\hline 30 & 11.8 \\
\hline 25 & 14.0 \\
\hline 15 & 16.1 \\
\hline 10 & 18.2 \\
\hline 5 & 20.2 \\
\hline 0 & 22.2 \\
\hline-5 & 24.1 \\
\hline
\end{tabular}

Note: Reduction calculated as $1-\left(0.995^{55-a g e}\right)$

Table 6: Ultimate Model 3 Changes in Actuarial Reduction and Delayed Retirement Credit

\begin{tabular}{|c|c|c|c|}
\hline \multirow[t]{2}{*}{$\begin{array}{l}\text { Age relative to } \\
\text { Normal Retirement } \\
\text { Age }\end{array}$} & \multirow[t]{2}{*}{$\begin{array}{l}\text { Implied age for } \\
\text { those claiming } \\
\text { benefits after } 2022\end{array}$} & \multicolumn{2}{|c|}{$\begin{array}{l}\text { Retirement benefits at different ages relative to benefit } \\
\text { at the Normal Retirement Age } \\
\text { (in percentage terms) }\end{array}$} \\
\hline & & Present Law & Model 3 \\
\hline NRA-5 & 62 & 70 & 63 \\
\hline NRA-4 & 63 & 75 & 69 \\
\hline NRA-3 & 64 & 80 & 75 \\
\hline NRA-2 & 65 & 86.7 & 83.3 \\
\hline NRA-1 & 66 & 93.3 & 91.7 \\
\hline NRA & 67 & 100 & 100 \\
\hline $\mathrm{NRA}+1$ & 68 & 108 & 110 \\
\hline $\mathrm{NRA}+2$ & 69 & 116 & 120 \\
\hline NRA+3 & 70 & 124 & 130 \\
\hline
\end{tabular}

The changes for NRA-5 and -4 begin for workers age 62 in 2009; those for NRA-3 to -1 are phased in for workers reaching 62 between 2008 and 2013; those for NRA+1 to +3 are phased in for workers reaching 65 between 2009 and 2016.

Source: Memorandum from the Office of the Chief Actuary, pages 12-13. 
Table 7: Model 3 Retirement Benefit Reductions From Life Expectancy and Early Retirement Adjustments, Relative to Scheduled Benefits, For Retired Worker Claiming Benefits at Age 62

\begin{tabular}{|l|c|}
\hline Age in 2002 & $\begin{array}{c}\text { Projected Percentage Retirement Benefit Reduction from Life } \\
\text { Expectancy and Early Reduction Factor Adjustments, } \\
\text { Assuming Benefits Claimed at Age 62 } \\
\text { (Relative to Scheduled Benefits in Current Law) }\end{array}$ \\
\hline 55 & 0.0 \\
\hline 50 & 12.2 \\
\hline 45 & 14.4 \\
\hline 40 & 16.5 \\
\hline 35 & 18.6 \\
\hline 30 & 20.6 \\
\hline 25 & 22.6 \\
\hline 20 & 24.5 \\
\hline 15 & 26.4 \\
\hline 10 & 28.2 \\
\hline 5 & 30.0 \\
\hline 0 & 31.7 \\
\hline-5 & 33.4 \\
\hline
\end{tabular}

Note: Reduction calculated as $1-0.9\left(0.995^{55-\text { age }}\right)$

Table 8: Model 3 Disability Benefit Reductions From Life Expectancy Adjustments, Relative to Scheduled Benefits in Current Law

\begin{tabular}{|l|c|}
\hline Year of entitlement to disability & $\begin{array}{c}\text { Projected Percentage Disability Benefit Reduction } \\
\text { (Relative to Scheduled Benefits in Current Law) }\end{array}$ \\
\hline 2010 & 1.0 \\
\hline 2020 & 5.8 \\
\hline 2030 & 10.4 \\
\hline 2040 & 14.8 \\
\hline 2050 & 19.0 \\
\hline 2060 & 22.9 \\
\hline 2070 & 26.7 \\
\hline 2075 & 28.5 \\
\hline
\end{tabular}

Source: Authors' calculations based on 2001 Trustees Report 
Table 9: Effect of Model 3 Long-Career Low-Earner Provision Relative to the Life Expectancy-Indexed PIA

\begin{tabular}{|c|c|c|c|c|c|}
\hline & \multicolumn{5}{|c|}{$\begin{array}{l}\text { Ultimate Percentage Increase in PIA }{ }^{1} \text { for Retirees with No Period of Disability } \\
\text { (Increase is Relative to the Life Expectancy-Indexed PIA, Starting in 2009) }\end{array}$} \\
\hline & \multicolumn{5}{|c|}{ Average earnings level (2002 wage levels) for years worked } \\
\hline $\begin{array}{l}\text { Number of } \\
\text { years of work }\end{array}$ & $\$ 5,000$ & $\begin{array}{c}\$ 11,318 \\
\text { (minimum } \\
\text { wage) }\end{array}$ & $\begin{array}{c}\$ 15,875 \\
\text { (scaled lower } \\
\text { earner) }\end{array}$ & $\begin{array}{l}\$ 22,635 \\
\text { (twice } \\
\text { minimum } \\
\text { wage) }\end{array}$ & $\begin{array}{c}\$ 35,277 \\
\text { (scaled } \\
\text { medium } \\
\text { earner) }\end{array}$ \\
\hline 10 & 0 & 0 & 0 & 0 & 0 \\
\hline 20 & 0 & 0 & 0 & 0 & 0 \\
\hline 30 & 12 & 12 & 10 & 7 & 2 \\
\hline 40 & 18 & 17 & 14 & 9 & 0 \\
\hline
\end{tabular}

${ }^{1}$ Ultimate increase is phased in over 10 years, 2009-2018. For workers with a given AIME, the increase is the same for 30 or more years of work. Increase reduced to 0 for 20 years of work or less. Based on intermediate assumptions of the 2001 Trustees Report.

Source: Memorandum from the Office of the Chief Actuary, page 10.

Table 10: Actuarial Balance for Model 3 without Personal Accounts

\begin{tabular}{|l|c|}
\hline & Percent of Payroll \\
\hline Current Law & -1.86 \\
\hline Benefit reduction for increased life expectancy & +1.17 \\
\hline Lower benefits for high earners & +.14 \\
\hline Increased minimum benefit & -.13 \\
\hline $\begin{array}{l}\text { Changed actuarial reduction and delayed retirement } \\
\text { increment }\end{array}$ & +.28 \\
\hline $\begin{array}{l}\text { Increased widow(er) benefit } \\
\text { Balance including interactions }\end{array}$ & -.08 \\
\hline Dedicated general revenue & -.55 \\
\hline Balance including dedicated general revenue & +.63 \\
\hline Soure: Merang & +.08 \\
\hline
\end{tabular}

Source: Memorandum from the Office of the Chief Actuary, pages 8-13 
Table 11: Specifications of Commission Individual Account Models

\begin{tabular}{|l|c|c|c|}
\hline Size of contribution & Model 1 & Model 2 & Model 3 \\
\hline $\begin{array}{l}\text { Real interest rate } \\
\text { charged on diverted } \\
\text { funds }\end{array}$ & 3.5 percent & $\begin{array}{c}\text { 4 percent of earnings, } \\
\text { up to \$1,000 } \\
\text { (indexed) }\end{array}$ & $\begin{array}{c}2.5 \text { percent of } \\
\text { earnings, up to } \\
\$ 1,000 \text { (indexed), } \\
\text { plus 1 percent of } \\
\text { earnings additional } \\
\text { contribution }\end{array}$ \\
\hline $\begin{array}{l}\text { Interest rate charged } \\
\text { on diverted funds } \\
\text { relative to ultimate } \\
\text { Trust Fund interest } \\
\text { rate (Treasury rate) }\end{array}$ & +0.5 percent & -1.0 percent & 2.5 percent \\
\hline
\end{tabular}

Source: President's Commission to Strengthen Social Security, Strengthening Social Security and Creating Personal Wealth for All Americans, page 17. 
Table 12: Subsidization of Individual Accounts under Model 2

\begin{tabular}{|c|c|c|c|}
\hline \multirow[t]{2}{*}{ In 2001 dollars } & \multicolumn{3}{|c|}{$\begin{array}{c}\text { Annuity per year for each member of two-earner couple under } \\
\text { Model 2, claiming benefits at age } 62 \text { in } 2072 \text {, and with } \\
\text { earnings equal to: }\end{array}$} \\
\hline & $\begin{array}{c}\text { Low earner } \\
(\$ 15,875 \text { in } 2002)\end{array}$ & $\begin{array}{l}\text { Medium earner } \\
(\$ 35,277 \text { in } 2002)\end{array}$ & $\begin{array}{c}\text { High earner } \\
(\$ 56,443 \text { in } 2002)\end{array}$ \\
\hline $\begin{array}{l}\text { Annuity per year assuming } 3 \\
\text { percent interest rate* }\end{array}$ & $\$ 3,952$ & $\$ 6,499$ & $\$ 6,759$ \\
\hline $\begin{array}{l}\text { - Annuity per year assuming } \\
2 \text { percent interest rate** }\end{array}$ & $\$ 2,833$ & $\$ 4,612$ & $\$ 4,768$ \\
\hline$=$ Subsidy per year & $\$ 1,120$ & $\$ 1,887$ & $\$ 1,991$ \\
\hline $\begin{array}{l}\text { Expected present value of } \\
\text { subsidy at } 3 \text { percent (in 2072) }\end{array}$ & $\$ 19,919$ & $\$ 33,559$ & $\$ 35,408$ \\
\hline
\end{tabular}

*Rate that would produce no present value impact on Social Security system (ignoring life insurance component associated with the individual account and the effects on the income taxation of benefits).

**Rate that is used to accumulate liabilities under Model 2.

Note: Annuitization assumes actuarially fair, CPI-indexed joint-and-two-thirds-survivor annuities and the mortality projections from the 2001 Trustees Report.

Table 13: Subsidization of Individual Accounts under Model 3

\begin{tabular}{|c|c|c|c|}
\hline \multirow[t]{2}{*}{ In 2001 dollars } & \multicolumn{3}{|c|}{$\begin{array}{l}\text { Annuity per year for each member of two-earner couple under } \\
\text { Model 3, claiming benefits at age } 62 \text { in } 2072 \text {, and with } \\
\text { earnings equal to: }\end{array}$} \\
\hline & $\begin{array}{c}\text { Low earner } \\
(\$ 15,875 \text { in 2002) }\end{array}$ & $\begin{array}{l}\text { Medium earner } \\
(\$ 35,277 \text { in } 2002)\end{array}$ & $\begin{array}{l}\text { High earner }(\$ 56,443 \\
\text { in } 2002)\end{array}$ \\
\hline $\begin{array}{l}\text { Annuity per year assuming } 3 \\
\text { percent interest rate* }\end{array}$ & $\$ 2,470$ & $\$ 5,491$ & $\$ 6,499$ \\
\hline $\begin{array}{l}\text { - Annuity per year assuming } 2.5 \\
\text { percent interest rate** }\end{array}$ & $\$ 2,091$ & $\$ 4,649$ & $\$ 5,474$ \\
\hline$=$ Subsidy per year & $\$ 379$ & $\$ 843$ & $\$ 1,025$ \\
\hline $\begin{array}{l}\text { Expected present value of } \\
\text { subsidy at } 3 \text { percent (in 2072) }\end{array}$ & $\$ 6,743$ & $\$ 14,988$ & $\$ 18,230$ \\
\hline
\end{tabular}

*Rate that would produce no present value impact on Social Security system (ignoring life insurance component associated with the individual account and the effects on the income taxation of benefits).

**Rate that is used to accumulate liabilities under Model 3.

Note: Annuitization assumes actuarially fair, CPI-indexed joint-and-two-thirds-survivor annuities and the mortality projections from the 2001 Trustees Report. 
Table 14: Actuarial Effects of Individual Accounts Inclusive of Ending Balance in Liability Accounts

\begin{tabular}{|c|c|c|c|c|}
\hline \multirow{2}{*}{$\begin{array}{l}\text { As percent of taxable } \\
\text { payroll, 2001-2075 }\end{array}$} & \multicolumn{2}{|c|}{ Model 2} & \multicolumn{2}{|c|}{ Model 3} \\
\hline & 67 percent & 100 percent & 67 percent & 100 percent \\
\hline $\begin{array}{l}\text { Impact of individual } \\
\text { accounts }\end{array}$ & -0.72 & -1.08 & -0.44 & -0.65 \\
\hline $\begin{array}{l}\text { Accumulated balances in } \\
\text { liability accounts in } 2075 \\
\text { as percent of taxable } \\
\text { payroll 2001-2075 } \\
\end{array}$ & 0.41 & 0.61 & 0.38 & 0.56 \\
\hline $\begin{array}{l}\text { Net impact, inclusive of } \\
\text { full ending accumulated } \\
\text { liability balance }\end{array}$ & -0.31 & -0.47 & -0.06 & -0.09 \\
\hline $\begin{array}{l}\text { Estimated present value of } \\
\text { benefit offsets from } \\
\text { accumulated liability } \\
\text { balance in } 2075 \text { as percent } \\
\text { of taxable payroll* }\end{array}$ & 0.31 & 0.46 & 0.32 & 0.48 \\
\hline $\begin{array}{l}\text { Net impact, inclusive of } \\
\text { estimated present value of } \\
\text { benefit offsets from ending } \\
\text { accumulated liability } \\
\text { balance }\end{array}$ & -0.41 & -0.62 & -0.12 & -0.17 \\
\hline
\end{tabular}

Source: Memorandum from the Office of the Chief Actuary; President's Commission to Strengthen Social Security, Strengthening Social Security and Creating Personal Wealth for All Americans, page 94; and authors' calculations

* The figures produced by the actuaries are the accumulated balances in the liability accounts at the end of the projection period. Since the balances would continue to be accrued at the lower rate on liabilities, and annuitized at the same lower rate, after the end of the projection period, their value to Social Security is reduced. We estimate that the value of $\$ 1$ in the liability account under Model 2 is worth approximately 75 cents to Social Security in present value, assuming the mean balance is owed by a worker approximately 45 to 50 years in age. Under Model 3 , a $\$ 1$ in the liability account is worth approximately 85 cents to Social Security in present value under the same assumption. The details of the calculation are available upon request to the authors. 
Table 15: Actuarial Effects of Individual Accounts and General Revenue Transfers under Model 2

\begin{tabular}{|l|c|c|c|}
\hline As percent of taxable payroll, 2001-2075 & \multicolumn{3}{|c|}{ Assumed participation rate } \\
\hline & 0 percent & 67 percent & 100 percent \\
\hline Actuarial balance with no individual accounts & 0.01 & 0.01 & 0.01 \\
\hline + Impact of individual accounts & NA & -0.72 & -1.08 \\
\hline $\begin{array}{l}\text { Actuarial balance with individual accounts but } \\
\text { no general revenue transfers }\end{array}$ & NA & -0.71 & -1.07 \\
\hline + General revenue transfers & NA & 0.84 & 1.23 \\
\hline = Actuarial balance & 0.01 & 0.13 & 0.16 \\
\hline
\end{tabular}

Source: Memorandum from the Office of the Chief Actuary; President's Commission to Strengthen Social Security, Strengthening Social Security and Creating Personal Wealth for All Americans, page 94; and authors' calculations

Table 16: Actuarial Effects of Individual Accounts and General Revenue Transfers under Model 3

\begin{tabular}{|l|c|c|c|}
\hline As percent of taxable payroll, 2001-2075 & \multicolumn{3}{|c|}{ Assumed participation rate } \\
\hline & 0 percent & 67 percent & 100 percent \\
\hline Actuarial balance with no individual accounts & 0.07 & 0.07 & 0.07 \\
\hline + Impact of individual accounts & NA & -0.44 & -0.65 \\
\hline $\begin{array}{l}\text { Actuarial balance with individual accounts but } \\
\text { no general revenue transfers beyond the } \\
\text { dedicated revenue in base plan }\end{array}$ & NA & -0.36 & -0.58 \\
\hline $\begin{array}{l}\text { + General revenue transfers in addition to } \\
\text { dedicated revenue in base plan }\end{array}$ & NA & 0.38 & 0.65 \\
\hline Actuarial balance & 0.01 & 0.02 & 0.07 \\
\hline
\end{tabular}

Source: Memorandum from the Office of the Chief Actuary; President's Commission to Strengthen Social Security, Strengthening Social Security and Creating Personal Wealth for All Americans, page 94; and authors' calculations. 
Table 17: General revenue transfers under Models 2 and 3

Assuming two-thirds of eligible workers contribute to individual accounts

\begin{tabular}{|l|c|c|}
\hline Percent of taxable payroll, 2001-2075 & Model 2 & Model 3 \\
\hline $\begin{array}{l}\text { Base plan transfers (independent of individual } \\
\text { account component) }\end{array}$ & NA & 0.63 \\
\hline $\begin{array}{l}\text { General revenue subsidies for additional one } \\
\text { percent contributions }\end{array}$ & NA & 0.15 \\
\hline $\begin{array}{l}\text { Transfers associated with individual account } \\
\text { component }\end{array}$ & 0.84 & 0.38 \\
\hline $\begin{array}{l}\text { Transfers required to insulate disabled from } \\
\text { benefit reductions prior to retirement }\end{array}$ & 0.30 & 0.17 \\
\hline As specified by Commission \\
\hline Total
\end{tabular}

Source: Memorandum from the Office of the Chief Actuary; President's Commission to Strengthen Social Security, Strengthening Social Security and Creating Personal Wealth for All Americans, page 94; and authors' calculations

Assuming all eligible workers contribute to individual accounts

\begin{tabular}{|l|c|c|}
\hline Percent of taxable payroll, 2001-2075 & Model 2 & Model 3 \\
\hline $\begin{array}{l}\text { Base plan transfers (independent of individual } \\
\text { account component) }\end{array}$ & NA & 0.63 \\
\hline $\begin{array}{l}\text { General revenue subsidies for additional one } \\
\text { percent contributions }\end{array}$ & NA & 0.23 \\
\hline $\begin{array}{l}\text { Transfers associated with individual account } \\
\text { component }\end{array}$ & 1.23 & 0.65 \\
\hline $\begin{array}{l}\text { Transfers required to insulate disabled from } \\
\text { benefit reductions prior to retirement } \\
\text { Awithout protection for the disabled) }\end{array}$ & 0.30 & 0.17 \\
\hline Total & 1.23 & 1.51 \\
\hline Including protection for the disabled & 1.53 & 1.68 \\
\hline
\end{tabular}

Source: Memorandum from the Office of the Chief Actuary; President's Commission to Strengthen Social Security, Strengthening Social Security and Creating Personal Wealth for All Americans, page 94; and authors' calculations 
Table 18: Impact of Models on Trust Fund Exhaustion Dates With No General Revenue Transfers (Except Dedicated Revenue under Model 3)

\begin{tabular}{|l|c|c|c|c|c|}
\hline & $\begin{array}{c}\text { Current } \\
\text { Law* }\end{array}$ & Model 1 & \multicolumn{2}{|c|}{ Model 2 } & $\begin{array}{c}\text { Model 3 } \\
\text { (67 percent participation) }\end{array}$ \\
\hline Participation rate & NA & $67 \%$ & $67 \%$ & $100 \%$ & $67 \%$ \\
\hline $\begin{array}{l}\text { First Year Cash } \\
\begin{array}{l}\text { Flow Becomes } \\
\text { Negative }\end{array}\end{array} 2016$ & 2012 & 2010 & 2006 & 2014 \\
\hline $\begin{array}{l}\text { Trust Fund } \\
\text { exhaustion date }\end{array}$ & 2038 & 2030 & 2030 & 2025 & 2039 \\
\hline
\end{tabular}

* Based on 2001 Trustees assumptions

Sources: Memorandum from the Office of the Chief Actuary, page 22; and author's calculations based on memorandum.

Table 19: Impact of Models on Treasury Borrowing

\begin{tabular}{|c|c|c|c|c|}
\hline \multicolumn{5}{|c|}{$\begin{array}{c}\text { Increase in Treasury Debt in the Hands of the Public } \\
\text { Relative to Paying Scheduled Benefits in Current Law } \\
\text { (in billions of } 2001 \text { dollars) }\end{array}$} \\
\hline & Model 1 & \multicolumn{2}{|c|}{ Model 2} & Model 3 \\
\hline & $\begin{array}{l}67 \text { percent } \\
\text { participation }\end{array}$ & $\begin{array}{c}67 \text { percent } \\
\text { participation }\end{array}$ & $\begin{array}{l}100 \text { percent } \\
\text { participation }\end{array}$ & $\begin{array}{c}67 \text { percent } \\
\text { participation }\end{array}$ \\
\hline 2010 & $\$ 443$ & $\$ 538$ & $\$ 802$ & $\$ 475$ \\
\hline 2020 & $\$ 1,342$ & $\$ 1,577$ & $\$ 2,383$ & $\$ 1,342$ \\
\hline 2030 & $\$ 2,473$ & $\$ 2,412$ & $\$ 3,928$ & $\$ 2,009$ \\
\hline 2040 & $\$ 3,689$ & $\$ 2,365$ & $\$ 4,735$ & $\$ 2,006$ \\
\hline 2050 & $\$ 4,756$ & $\$ 644$ & $\$ 3,889$ & $\$ 854$ \\
\hline 2060 & $\$ 5,494$ & $-\$ 3,816$ & $\$ 649$ & $-\$ 2,183$ \\
\hline 2070 & $\$ 5,902$ & $-\$ 12,212$ & $-\$ 6,382$ & $-\$ 7,866$ \\
\hline 2076 & $\$ 6,014$ & $-\$ 19,776$ & $-\$ 12,956$ & $-\$ 12,955$ \\
\hline
\end{tabular}

Note: Assumes no change in interest rates.

Source: Memorandum from the Office of the Chief Actuary, pages 53-62. 
Table 20: Expected combined benefit levels for each member of two-earner couples claiming at age 65 in 2052

Model 2

\begin{tabular}{|l|c|c|c|}
\hline In 2001 dollars & $\begin{array}{c}\text { Low earner } \\
(\$ 15,875 \text { in 2002) }\end{array}$ & $\begin{array}{c}\text { Medium earner } \\
(\$ 35,277 \text { in 2002) }\end{array}$ & $\begin{array}{c}\text { High earner } \\
(\$ 56,443 \text { in 2002) }\end{array}$ \\
\hline Scheduled benefit & $\$ 986$ & $\$ 1,628$ & $\$ 2,151$ \\
\hline - Benefit change for all & $-\$ 180$ & $-\$ 529$ & $-\$ 699$ \\
\hline $\begin{array}{l}\text { + Annuity from individual } \\
\text { account }\end{array}$ & $\$ 478$ & $\$ 819$ & $\$ 860$ \\
\hline - Offset from liability account & $-\$ 234$ & $-\$ 392$ & $-\$ 407$ \\
\hline$=$ Total expected benefit & $\$ 1,050$ & $\$ 1,525$ & $\$ 1,907$ \\
\hline $\begin{array}{l}\text { Percent change without the } \\
\text { individual account (change } \\
\text { from scheduled benefits) }\end{array}$ & $-18 \%$ & $-33 \%$ & $-33 \%$ \\
\hline $\begin{array}{l}\text { Percent change with the } \\
\text { account (change from } \\
\text { scheduled benefits) }\end{array}$ & $+7 \%$ & $-6 \%$ & $-11 \%$ \\
\hline
\end{tabular}

Model 3

\begin{tabular}{|l|c|c|c|}
\hline In 2001 dollars & $\begin{array}{c}\text { Low earner } \\
(\$ 15,875 \text { in 2002) }\end{array}$ & $\begin{array}{c}\text { Medium earner } \\
(\$ 35,277 \text { in 2002) }\end{array}$ & $\begin{array}{c}\text { High earner } \\
(\$ 56,443 \text { in 2002) }\end{array}$ \\
\hline Scheduled benefit & $\$ 986$ & $\$ 1,628$ & $\$ 2,151$ \\
\hline - Benefit change for all & $-\$ 129$ & $-\$ 353$ & $-\$ 508$ \\
\hline $\begin{array}{l}\text { + Annuity from individual } \\
\text { account }\end{array}$ & $\$ 418$ & $\$ 930$ & $\$ 1,243$ \\
\hline - Offset from liability account & $-\$ 173$ & $-\$ 383$ & $-\$ 465$ \\
\hline$=$ Total expected benefit & $\$ 1,103$ & $\$ 1,821$ & $\$ 2,423$ \\
\hline $\begin{array}{l}\text { Percent change without the } \\
\text { individual account (change } \\
\text { from scheduled benefits) }\end{array}$ & $-13 \%$ & $-22 \%$ & $-24 \%$ \\
\hline $\begin{array}{l}\text { Percent change with the } \\
\text { account (change from } \\
\text { scheduled benefits) }\end{array}$ & $+12 \%$ & $+12 \%$ & $+13 \%$ \\
\hline $\begin{array}{l}\text { Percent change with the } \\
\text { account but without one } \\
\text { percent additional } \\
\text { contribution (change from } \\
\text { scheduled benefits) }\end{array}$ & $0 \%$ & $-5 \%$ & $-7 \%$ \\
\hline
\end{tabular}

Source: Memorandum from the Office of the Chief Actuary, pages 75-76, and authors' calculations. Based on intermediate assumptions from 2001 Trustees Report and an assumed net return (after administrative costs and inflation) of 4.6 percent per year. Assumptions are identical to those adopted by the actuaries in analyzing the Commission plans. 
Table 21: Expected combined benefit levels for each member of two-earner couples claiming at age 65 in 2075

Model 2
\begin{tabular}{|l|c|c|c|}
\hline $\begin{array}{l}\text { Monthly amount, in 2001 } \\
\text { dollars }\end{array}$ & $\begin{array}{c}\text { Low earner } \\
(\$ 15,875 \text { in 2002) }\end{array}$ & $\begin{array}{c}\text { Medium earner } \\
(\$ 35,277 \text { in 2002) }\end{array}$ & $\begin{array}{c}\text { High earner } \\
(\$ 56,443 \text { in 2002) }\end{array}$ \\
\hline Scheduled benefit & $\$ 1,231$ & $\$ 2,032$ & $\$ 2,685$ \\
\hline - Benefit change for all & $-\$ 425$ & $-\$ 933$ & $-\$ 1,233$ \\
\hline $\begin{array}{l}\text { + Annuity from individual } \\
\text { account }\end{array}$ & $\$ 577$ & $\$ 989$ & $\$ 1,040$ \\
\hline - Offset from liability account & $-\$ 281$ & $-\$ 473$ & $-\$ 489$ \\
\hline$=$ Total expected benefit & $\$ 1,102$ & $\$ 1,615$ & $\$ 2,003$ \\
\hline & & & $-46 \%$ \\
\hline $\begin{array}{l}\text { Percent change without } \\
\text { account (relative to scheduled } \\
\text { benefit) }\end{array}$ & $-35 \%$ & $-46 \%$ & $-25 \%$ \\
\hline $\begin{array}{l}\text { Percent change with account } \\
\text { (relative to scheduled benefit })\end{array}$ & $-10 \%$ & $-21 \%$ & \\
\hline
\end{tabular}

Model 3

\begin{tabular}{|l|c|c|c|}
\hline $\begin{array}{l}\text { Monthly amount, in 2001 } \\
\text { dollars }\end{array}$ & $\begin{array}{c}\text { Low earner } \\
(\$ 15,875 \text { in 2002) }\end{array}$ & $\begin{array}{c}\text { Medium earner } \\
(\$ 35,277 \text { in 2002) }\end{array}$ & $\begin{array}{c}\text { High earner } \\
(\$ 56,443 \text { in 2002) }\end{array}$ \\
\hline Scheduled benefit & $\$ 1,231$ & $\$ 2,032$ & $\$ 2,685$ \\
\hline - Benefit change for all & $-\$ 273$ & $-\$ 607$ & $-\$ 848$ \\
\hline $\begin{array}{l}\text { + Annuity from individual } \\
\text { account (including 1 percent } \\
\text { additional contribution) }\end{array}$ & $\$ 505$ & $\$ 1,123$ & $\$ 1,502$ \\
\hline - Offset from liability account \\
$=$ Total expected benefit & $-\$ 208$ & $-\$ 462$ & $-\$ 560$ \\
\hline $\begin{array}{l}\text { Percent change without } \\
\text { account (relative to scheduled } \\
\text { benefit) }\end{array}$ & $-22 \%$ & $\$ 2,086$ & $\$ 2,779$ \\
\hline $\begin{array}{l}\text { Percent change with account } \\
\text { (relative to scheduled benefit) }\end{array}$ & $+2 \%$ & $-30 \%$ & $-32 \%$ \\
\hline $\begin{array}{l}\text { Percent change with account } \\
\text { but without additional one } \\
\text { percent contributions (relative } \\
\text { to scheduled benefit) }\end{array}$ & $-9 \%$ & $-12 \%$ & $-15 \%$ \\
\hline
\end{tabular}

Note: Based on intermediate assumptions from 2001 Trustees Report and assumed net return (after administrative costs) of 4.6 percent per year. Return assumption reflects 3.0 percent ultimate real yield on Treasury securities; 6.5 percent return on equity; 3.5 percent return on corporate bonds; and 0.3 percent administrative costs. The portfolio is assumed to be 50 percent bonds and 50 percent equity. The bond component comprises 60 percent corporate bonds and 40 percent Treasury bonds. Annuitization assumes actuarially fair, CPI-indexed joint-and-two-thirdssurvivor annuities and the mortality projections from the 2001 Trustees Report.

Source: Memorandum from the Office of the Chief Actuary, pages 75-76, and authors' calculations. 
Table 22: Expected combined benefit levels for each member of two-earner couples claiming at age 62 in 2049

Model 2

\begin{tabular}{|l|c|c|c|}
\hline Monthly amount, in 2001 dollars & $\begin{array}{c}\text { Low earner } \\
(\$ 15,875 \text { in 202) }\end{array}$ & $\begin{array}{c}\text { Medium earner } \\
(\$ 35,277 \text { in 2002) }\end{array}$ & $\begin{array}{c}\text { High earner } \\
(\$ 56,443 \text { in 2002) }\end{array}$ \\
\hline Scheduled benefit & $\$ 796$ & $\$ 1,314$ & $\$ 1,737$ \\
\hline - Benefit change for all & $-\$ 145$ & $-\$ 427$ & $\$ 564$ \\
\hline + Annuity from individual account & $\$ 378$ & $\$ 632$ & $\$ 664$ \\
\hline - Offset from liability account & $-\$ 195$ & $\$ 318$ & $\$ 329$ \\
\hline$=$ Total expected benefit & $\$ 833$ & $\$ 1,201$ & $\$ 1,507$ \\
\hline & & & $-33 \%$ \\
\hline $\begin{array}{l}\text { Percent change without account } \\
\text { (relative to scheduled benefit) }\end{array}$ & $-18 \%$ & $-33 \%$ & $-13 \%$ \\
\hline $\begin{array}{l}\text { Percent change with account } \\
\text { (relative to scheduled benefit) }\end{array}$ & $5 \%$ & $-9 \%$ & \\
\hline
\end{tabular}

Model 3

\begin{tabular}{|l|c|c|c|}
\hline In 2001 dollars & $\begin{array}{c}\text { Low earner } \\
(\$ 15,875 \text { in 2002) }\end{array}$ & $\begin{array}{c}\text { Medium earner } \\
(\$ 35,277 \text { in 2002) }\end{array}$ & $\begin{array}{c}\text { High earner } \\
(\$ 56,443 \text { in 2002) }\end{array}$ \\
\hline Scheduled benefit & $\$ 796$ & $\$ 1,314$ & $\$ 1,737$ \\
\hline - Benefit change for all & $-\$ 104$ & $-\$ 285$ & $\$ 410$ \\
\hline $\begin{array}{l}\text { + Annuity from individual account } \\
\text { (including 1 percent additional } \\
\text { contribution) }\end{array}$ & $\$ 330$ & $\$ 735$ & $\$ 968$ \\
\hline - Offset from liability account & $-\$ 144$ & $-\$ 324$ & $-\$ 377$ \\
\hline $\begin{array}{l}\text { - Reduction factor for early } \\
\text { retirement }\end{array}$ & $-\$ 80$ & $-\$ 131$ & $-\$ 174$ \\
\hline$=$ Total expected benefit & $\$ 799$ & $\$ 1,309$ & $\$ 1,744$ \\
\hline $\begin{array}{l}\text { Percent change without account } \\
\text { (relative to scheduled benefit) }\end{array}$ & $-23 \%$ & $-32 \%$ & $-34 \%$ \\
\hline $\begin{array}{l}\text { Percent change with account } \\
\text { (relative to scheduled benefit) }\end{array}$ & $0 \%$ & $0 \%$ & $0 \%$ \\
\hline $\begin{array}{l}\text { Percent change with account but } \\
\text { without additional one percent } \\
\text { contributions (relative to } \\
\text { scheduled benefit) }\end{array}$ & $-12 \%$ & $-16 \%$ & $-19 \%$ \\
\hline
\end{tabular}

Source: Memorandum from the Office of the Chief Actuary, pages 75-76, and authors' calculations. Based on intermediate assumptions from 2001 Trustees Report and assumed net return (after administrative costs and inflation) of 4.6 percent per year. Assumptions are identical to those adopted by the actuaries in analyzing the Commission plans. 
Table 23: Expected combined benefit levels for each member of two-earner couples claiming at age 62 in 2072

Model 2
\begin{tabular}{|l|c|c|c|}
\hline $\begin{array}{l}\text { Monthly amount, in 2001 } \\
\text { dollars }\end{array}$ & $\begin{array}{c}\text { Low earner } \\
(\$ 15,875 \text { in 2002) }\end{array}$ & $\begin{array}{c}\text { Medium earner } \\
(\$ 35,277 \text { in 2002) }\end{array}$ & $\begin{array}{c}\text { High earner } \\
(\$ 56,443 \text { in 2002) }\end{array}$ \\
\hline Scheduled benefit & $\$ 994$ & $\$ 1,641$ & $\$ 2,168$ \\
\hline - Benefit change for all & $-\$ 343$ & $-\$ 753$ & $-\$ 995$ \\
\hline $\begin{array}{l}\text { + Annuity from individual } \\
\text { account }\end{array}$ & $\$ 458$ & $\$ 766$ & $\$ 805$ \\
\hline - Offset from liability account & $-\$ 236$ & $-\$ 384$ & $-\$ 397$ \\
\hline$=$ Total expected benefit & $\$ 873$ & $\$ 1,269$ & $\$ 1,580$ \\
\hline & & & $-46 \%$ \\
\hline $\begin{array}{l}\text { Percent change without } \\
\text { account (relative to scheduled } \\
\text { benefit) }\end{array}$ & $-35 \%$ & $-46 \%$ & $-27 \%$ \\
\hline $\begin{array}{l}\text { Percent change with account } \\
\text { (relative to scheduled benefit })\end{array}$ & $-12 \%$ & $-23 \%$ & \\
\hline
\end{tabular}

\section{Model 3}

\begin{tabular}{|l|c|c|c|}
\hline $\begin{array}{l}\text { Monthly amount, in 2001 } \\
\text { dollars }\end{array}$ & $\begin{array}{c}\text { Low earner } \\
(\$ 15,875 \text { in 2002) }\end{array}$ & $\begin{array}{c}\text { Medium earner } \\
(\$ 35,277 \text { in 2002) }\end{array}$ & $\begin{array}{c}\text { High earner } \\
(\$ 56,443 \text { in 2002) }\end{array}$ \\
\hline Scheduled benefit & $\$ 994$ & $\$ 1,641$ & $\$ 2,168$ \\
\hline - Benefit change for all & $-\$ 221$ & $-\$ 491$ & $-\$ 685$ \\
\hline $\begin{array}{l}\text { + Annuity from individual } \\
\text { account (including 1 percent } \\
\text { additional contribution) }\end{array}$ & $\$ 400$ & $\$ 890$ & $\$ 1,173$ \\
\hline - Offset from liability account & $-\$ 174$ & $-\$ 391$ & $-\$ 456$ \\
\hline - Early reduction factor & $-\$ 99$ & $-\$ 164$ & $-\$ 217$ \\
\hline$=$ Total expected benefit & $\$ 900$ & $\$ 1,485$ & $\$ 1,983$ \\
\hline & & & $-42 \%$ \\
\hline $\begin{array}{l}\text { Percent change without } \\
\text { account (relative to scheduled } \\
\text { benefit) }\end{array}$ & $-32 \%$ & $-40 \%$ & $-9 \%$ \\
\hline $\begin{array}{l}\text { Percent change with account } \\
\text { (relative to scheduled benefit })\end{array}$ & $-9 \%$ & $-10 \%$ & $-27 \%$ \\
\hline $\begin{array}{l}\text { Percent change with account } \\
\text { but without additional one } \\
\text { percent contributions (relative } \\
\text { to scheduled benefit) }\end{array}$ & $-21 \%$ & $-24 \%$ & \\
\hline
\end{tabular}

Note: Based on intermediate assumptions from 2001 Trustees Report and assumed net return (after administrative costs) of 4.6 percent per year. Return assumption reflects 3.0 percent ultimate real yield on Treasury securities; 6.5 percent return on equity; 3.5 percent return on corporate bonds; and 0.3 percent administrative costs. The portfolio is assumed to be 50 percent bonds and 50 percent equity. The bond component comprises 60 percent corporate bonds and 40 percent Treasury bonds. Annuitization assumes actuarially fair, CPI-indexed joint-and-two-thirdssurvivor annuities and the mortality projections from the 2001 Trustees Report.

Source: Memorandum from the Office of the Chief Actuary, pages 75-76, and authors' calculations. 
Table 24: Expected combined benefit levels for one-earner couples claiming at age 65 in 2052

Model 2

\begin{tabular}{|l|c|c|c|}
\hline $\begin{array}{l}\text { Monthly amount, in 2001 } \\
\text { dollars }\end{array}$ & $\begin{array}{c}\text { Low earner } \\
(\$ 15,875 \text { in 2002) }\end{array}$ & $\begin{array}{c}\text { Medium earner } \\
(\$ 35,277 \text { in 2002) }\end{array}$ & $\begin{array}{c}\text { High earner } \\
(\$ 56,443 \text { in 2002) }\end{array}$ \\
\hline Scheduled benefit & $\$ 1,460$ & $\$ 2,410$ & $\$ 3,185$ \\
\hline - Benefit change for all & $\$(266)$ & $\$(783)$ & $\$(1,035)$ \\
\hline $\begin{array}{l}\text { + Annuity from individual } \\
\text { account }\end{array}$ & $\$ 484$ & $\$ 821$ & $\$ 863$ \\
\hline - Offset from liability account & $\$(239)$ & $\$(395)$ & $\$(408)$ \\
\hline$=$ Total expected benefit & $\$ 1,438$ & $\$ 2,053$ & $\$ 2,605$ \\
\hline & & & $-32 \%$ \\
\hline $\begin{array}{l}\text { Percent change without } \\
\text { account (relative to scheduled } \\
\text { benefit) }\end{array}$ & $-18 \%$ & $-32 \%$ & $-18 \%$ \\
\hline $\begin{array}{l}\text { Percent change with account } \\
\text { (relative to scheduled benefit) }\end{array}$ & $-2 \%$ & $-15 \%$ & \\
\hline
\end{tabular}

\section{Model 3}

\begin{tabular}{|c|c|c|c|c|c|}
\hline $\begin{array}{l}\text { Monthly amount, in } 2001 \\
\text { dollars }\end{array}$ & $\begin{array}{c}\text { Low earner } \\
(\$ 15,875 \text { in } 2002)\end{array}$ & \multicolumn{2}{|c|}{$\begin{array}{c}\text { Medium earner } \\
(\$ 35,277 \text { in 2002) }\end{array}$} & \multicolumn{2}{|c|}{$\begin{array}{c}\text { High earner } \\
(\$ 56,443 \text { in } 2002)\end{array}$} \\
\hline Scheduled benefit & $\$ 1,460$ & $\$$ & 2,410 & & 3,185 \\
\hline - Benefit change for all & $\$(191)$ & $\$$ & $(523)$ & $\$$ & $(752)$ \\
\hline $\begin{array}{l}+ \text { Annuity from individual } \\
\text { account (including } 1 \text { percent } \\
\text { additional contribution) }\end{array}$ & $\$ 424$ & $\$$ & 942 & $\$$ & 1,247 \\
\hline - Offset from liability account & $\$(177)$ & $\$$ & (398) & $\$$ & $(470)$ \\
\hline$=$ Total expected benefit & $\$ 1,515$ & $\$$ & 2,431 & $\$$ & 3,210 \\
\hline $\begin{array}{l}\text { Percent change without } \\
\text { account (relative to scheduled } \\
\text { benefit) }\end{array}$ & $-13 \%$ & & $22 \%$ & & $-24 \%$ \\
\hline $\begin{array}{l}\text { Percent change with account } \\
\text { (relative to scheduled benefit) }\end{array}$ & $4 \%$ & & $1 \%$ & & $1 \%$ \\
\hline $\begin{array}{l}\text { Percent change with account } \\
\text { but without additional one } \\
\text { percent contributions (relative } \\
\text { to scheduled benefit) }\end{array}$ & $-4 \%$ & & $-10 \%$ & & $-13 \%$ \\
\hline
\end{tabular}

Note: Based on intermediate assumptions from 2001 Trustees Report and assumed net return (after administrative costs) of 4.6 percent per year. Return assumption reflects 3.0 percent ultimate real yield on Treasury securities; 6.5 percent return on equity; 3.5 percent return on corporate bonds; and 0.3 percent administrative costs. The portfolio is assumed to be 50 percent bonds and 50 percent equity. The bond component comprises 60 percent corporate bonds and 40 percent Treasury bonds. Annuitization assumes actuarially fair, CPI-indexed joint-and-two-thirdssurvivor annuities and the mortality projections from the 2001 Trustees Report.

Source: Memorandum from the Office of the Chief Actuary, pages 78-79, and authors' calculations. 
Table 25: Expected combined benefit levels for one-earner couples claiming at age 65 in 2075

Model 2

\begin{tabular}{|l|c|c|c|}
\hline $\begin{array}{l}\text { Monthly amount, in 2001 } \\
\text { dollars }\end{array}$ & $\begin{array}{c}\text { Low earner } \\
(\$ 15,875 \text { in 2002) }\end{array}$ & $\begin{array}{c}\text { Medium earner } \\
(\$ 35,277 \text { in 2002) }\end{array}$ & $\begin{array}{c}\text { High earner } \\
(\$ 56,443 \text { in 2002) }\end{array}$ \\
\hline Scheduled benefit & $\$ 1,823$ & $\$ 3,009$ & $\$ 3,975$ \\
\hline - Benefit change for all & $-\$ 629$ & $-\$ 1,381$ & $-\$ 1,825$ \\
\hline $\begin{array}{l}+ \text { Annuity from individual } \\
\text { account }\end{array}$ & $\$ 577$ & $\$ 989$ & $\$ 1,040$ \\
\hline - Offset from liability account & $-\$ 281$ & $-\$ 473$ & $-\$ 489$ \\
\hline$=$ Total expected benefit & $\$ 1,490$ & $\$ 2,144$ & $\$ 2,701$ \\
\hline & & $-46 \%$ & $-46 \%$ \\
\hline $\begin{array}{l}\text { Percent change without } \\
\text { account (relative to scheduled } \\
\text { benefit) }\end{array}$ & $-35 \%$ & & $-32 \%$ \\
\hline $\begin{array}{l}\text { Percent change with account } \\
\text { (relative to scheduled benefit) }\end{array}$ & $-18 \%$ & $-29 \%$ & \\
\hline
\end{tabular}

\section{Model 3}

\begin{tabular}{|l|c|c|c|}
\hline $\begin{array}{l}\text { Monthly amount, in 2001 } \\
\text { dollars }\end{array}$ & $\begin{array}{c}\text { Low earner } \\
(\$ 15,875 \text { in 2002) }\end{array}$ & $\begin{array}{c}\text { Medium earner } \\
(\$ 35,277 \text { in 2002) }\end{array}$ & $\begin{array}{c}\text { High earner } \\
(\$ 56,443 \text { in 2002) }\end{array}$ \\
\hline \begin{tabular}{l} 
Scheduled benefit \\
\hline - Benefit change for all
\end{tabular} & $-\$ 404$ & $\$ 3,009$ & $\$ 3,975$ \\
\hline $\begin{array}{l}\text { + Annuity from individual } \\
\text { account (including 1 percent } \\
\text { additional contribution) }\end{array}$ & $\$ 505$ & $\$ 1,123$ & $-\$ 1,255$ \\
\hline - Offset from liability account & $-\$ 208$ & $-\$ 462$ & $-\$ 502$ \\
\hline$=$ Total expected benefit & $\$ 1,716$ & $\$ 2,771$ & $\$ 3,662$ \\
\hline $\begin{array}{l}\text { Percent change without } \\
\text { account (relative to scheduled } \\
\text { benefit) }\end{array}$ & $-22 \%$ & $-30 \%$ & $-32 \%$ \\
\hline $\begin{array}{l}\text { Percent change with account } \\
\text { (relative to scheduled benefit) }\end{array}$ & $-6 \%$ & $-8 \%$ & $-8 \%$ \\
\hline $\begin{array}{l}\text { Percent change with account } \\
\text { but without additional one } \\
\text { percent contributions (relative } \\
\text { to scheduled benefit) }\end{array}$ & $-14 \%$ & $-19 \%$ & $-21 \%$ \\
\hline
\end{tabular}

Note: Based on intermediate assumptions from 2001 Trustees Report and assumed net return (after administrative costs) of 4.6 percent per year. Return assumption reflects 3.0 percent ultimate real yield on Treasury securities; 6.5 percent return on equity; 3.5 percent return on corporate bonds; and 0.3 percent administrative costs. The portfolio is assumed to be 50 percent bonds and 50 percent equity. The bond component comprises 60 percent corporate bonds and 40 percent Treasury bonds. Annuitization assumes actuarially fair, CPI-indexed joint-and-two-thirdssurvivor annuities and the mortality projections from the 2001 Trustees Report.

Source: Memorandum from the Office of the Chief Actuary, pages 78-79, and authors' calculations. 
Table 26: Expected combined benefit levels for one-earner couples claiming at age 62 in 2049

Model 2
\begin{tabular}{|l|c|c|c|}
\hline $\begin{array}{l}\text { Monthly amount, in 2001 } \\
\text { dollars }\end{array}$ & $\begin{array}{c}\text { Low earner } \\
(\$ 15,875 \text { in 2002) }\end{array}$ & $\begin{array}{c}\text { Medium earner } \\
(\$ 35,277 \text { in 2002) }\end{array}$ & $\begin{array}{c}\text { High earner } \\
(\$ 56,443 \text { in 2002) }\end{array}$ \\
\hline Scheduled benefit & $\$ 1,166$ & $\$ 1,924$ & $\$ 2,543$ \\
\hline - Benefit change for all & $\$(213)$ & $\$(625)$ & $\$(826)$ \\
\hline $\begin{array}{l}\text { + Annuity from individual } \\
\text { account }\end{array}$ & $\$ 378$ & $\$ 632$ & $\$ 664$ \\
\hline - Offset from liability account & $\$(195)$ & $\$(318)$ & $\$(329)$ \\
\hline$=$ Total expected benefit & $\$ 1,135$ & $\$ 1,613$ & $\$ 2,052$ \\
\hline & & & $-32 \%$ \\
\hline $\begin{array}{l}\text { Percent change without } \\
\text { account (relative to scheduled } \\
\text { benefit) }\end{array}$ & $-18 \%$ & $-32 \%$ & $-19 \%$ \\
\hline $\begin{array}{l}\text { Percent change with account } \\
\text { (relative to scheduled benefit) }\end{array}$ & $-3 \%$ & $-16 \%$ & \\
\hline
\end{tabular}

Model 3

\begin{tabular}{|l|c|c|c|}
\hline $\begin{array}{l}\text { Monthly amount, in 2001 } \\
\text { dollars }\end{array}$ & $\begin{array}{c}\text { Low earner } \\
(\$ 15,875 \text { in 2002) }\end{array}$ & $\begin{array}{c}\text { Medium earner } \\
(\$ 35,277 \text { in 2002) }\end{array}$ & $\begin{array}{c}\text { High earner } \\
(\$ 56,443 \text { in 2002) }\end{array}$ \\
\hline Scheduled benefit & $\$ 1,166$ & $\$ 1,924$ & $\$ 2,543$ \\
\hline - Benefit change for all & $\$(153)$ & $\$(418)$ & $\$(600)$ \\
\hline $\begin{array}{l}\text { + Annuity from individual } \\
\text { account (including 1 percent } \\
\text { additional contribution) }\end{array}$ & $\$ 330$ & $\$ 735$ & $\$ 968$ \\
\hline- Offset from liability account & $\$(144)$ & $\$(324)$ & $\$(377)$ \\
\hline - Early reduction factor & $\$(117)$ & $\$(192)$ & $\$(254)$ \\
\hline$=$ Total expected benefit & $\$ 1,083$ & $\$ 1,725$ & $\$ 2,279$ \\
\hline & & & $-34 \%$ \\
\hline $\begin{array}{l}\text { Percent change without } \\
\text { account (relative to scheduled } \\
\text { benefit) }\end{array}$ & $-23 \%$ & $-32 \%$ & $-10 \%$ \\
\hline $\begin{array}{l}\text { Percent change with account } \\
\text { (relative to scheduled benefit) }\end{array}$ & $-7 \%$ & $-10 \%$ & $-24 \%$ \\
\hline $\begin{array}{l}\text { Percent change with account } \\
\text { but without additional one } \\
\text { percent contributions (relative } \\
\text { to scheduled benefit) }\end{array}$ & $-15 \%$ & $-21 \%$ & \\
\hline
\end{tabular}

Note: Based on intermediate assumptions from 2001 Trustees Report and assumed net return (after administrative costs) of 4.6 percent per year. Return assumption reflects 3.0 percent ultimate real yield on Treasury securities; 6.5 percent return on equity; 3.5 percent return on corporate bonds; and 0.3 percent administrative costs. The portfolio is assumed to be 50 percent bonds and 50 percent equity. The bond component comprises 60 percent corporate bonds and 40 percent Treasury bonds. Annuitization assumes actuarially fair, CPI-indexed joint-and-two-thirdssurvivor annuities and the mortality projections from the 2001 Trustees Report. 
Table 27: Expected combined benefit levels for one-earner couples claiming at age 62 in 2072

Model 2

\begin{tabular}{|l|c|c|c|}
\hline $\begin{array}{l}\text { Monthly amount, in 2001 } \\
\text { dollars }\end{array}$ & $\begin{array}{c}\text { Low earner } \\
(\$ 15,875 \text { in 2002) }\end{array}$ & $\begin{array}{c}\text { Medium earner } \\
(\$ 35,277 \text { in 2002) }\end{array}$ & $\begin{array}{c}\text { High earner } \\
(\$ 56,443 \text { in 2002) }\end{array}$ \\
\hline Scheduled benefit & $\$ 1,455$ & $\$ 2,402$ & $\$ 3,174$ \\
\hline - Benefit change for all & $-\$ 502$ & $-\$ 1,103$ & $-\$ 1,457$ \\
\hline $\begin{array}{l}\text { + Annuity from individual } \\
\text { account }\end{array}$ & $\$ 458$ & $\$ 766$ & $\$ 805$ \\
\hline - Offset from liability account & $-\$ 236$ & $-\$ 384$ & $-\$ 397$ \\
\hline$=$ Total expected benefit & $\$ 1,175$ & $\$ 1,681$ & $\$ 2,125$ \\
\hline & & & $-46 \%$ \\
\hline $\begin{array}{l}\text { Percent change without } \\
\text { account (relative to scheduled } \\
\text { benefit) }\end{array}$ & $-35 \%$ & $-46 \%$ & $-33 \%$ \\
\hline $\begin{array}{l}\text { Percent change with account } \\
\text { (relative to scheduled benefit) }\end{array}$ & $-19 \%$ & $-30 \%$ & \\
\hline
\end{tabular}

\section{Model 3}

\begin{tabular}{|l|c|c|c|}
\hline $\begin{array}{l}\text { Monthly amount, in 2001 } \\
\text { dollars }\end{array}$ & $\begin{array}{c}\text { Low earner } \\
(\$ 15,875 \text { in 2002) }\end{array}$ & $\begin{array}{c}\text { Medium earner } \\
(\$ 35,277 \text { in 2002) }\end{array}$ & $\begin{array}{c}\text { High earner } \\
(\$ 56,443 \text { in 2002) }\end{array}$ \\
\hline \begin{tabular}{l} 
Scheduled benefit \\
\hline - Benefit change for all
\end{tabular} & $-\$ 323$ & $-\$ 718$ & $\$ 3,174$ \\
\hline $\begin{array}{l}\text { + Annuity from individual } \\
\text { account (including 1 percent } \\
\text { additional contribution) }\end{array}$ & $\$ 400$ & $\$ 890$ & $-\$ 1,003$ \\
\hline - Offset from liability account & $-\$ 174$ & $-\$ 391$ & $-\$ 456$ \\
\hline - Early reduction factor & $-\$ 146$ & $-\$ 240$ & $-\$ 317$ \\
\hline$=$ Total expected benefit & $\$ 1,213$ & $\$ 1,943$ & $\$ 2,571$ \\
\hline $\begin{array}{l}\text { Percent change without } \\
\text { account (relative to scheduled } \\
\text { benefit) }\end{array}$ & $-32 \%$ & $-40 \%$ & $-42 \%$ \\
\hline $\begin{array}{l}\text { Percent change with account } \\
\text { (relative to scheduled benefit) }\end{array}$ & $-17 \%$ & $-19 \%$ & $-19 \%$ \\
\hline $\begin{array}{l}\text { Percent change with account } \\
\text { but without additional one } \\
\text { percent contributions (relative } \\
\text { to scheduled benefit) }\end{array}$ & $-25 \%$ & $-30 \%$ & $-32 \%$ \\
\hline
\end{tabular}

Note: Based on intermediate assumptions from 2001 Trustees Report and assumed net return (after administrative costs) of 4.6 percent per year. Return assumption reflects 3.0 percent ultimate real yield on Treasury securities; 6.5 percent return on equity; 3.5 percent return on corporate bonds; and 0.3 percent administrative costs. The portfolio is assumed to be 50 percent bonds and 50 percent equity. The bond component comprises 60 percent corporate bonds and 40 percent Treasury bonds. Annuitization assumes actuarially fair, CPI-indexed joint-and-two-thirdssurvivor annuities and the mortality projections from the 2001 Trustees Report.

Source: Memorandum from the Office of the Chief Actuary, pages 78-79, and authors' calculations. 
Table 28: Expected combined benefit levels for each member of two-earner couples claiming at age 62 in 2072 with and without subsidy to individual account

Model 2

\begin{tabular}{|c|c|c|c|}
\hline & $\begin{array}{c}\text { Low earner } \\
(\$ 15,875 \text { in } 2002)\end{array}$ & $\begin{array}{l}\text { Medium earner } \\
(\$ 35,277 \text { in } 2002)\end{array}$ & $\begin{array}{c}\text { High earner } \\
(\$ 56,443 \text { in } 2002)\end{array}$ \\
\hline $\begin{array}{l}\text { Percent change without } \\
\text { account (relative to scheduled } \\
\text { benefit) }\end{array}$ & $-35 \%$ & $-46 \%$ & $-46 \%$ \\
\hline $\begin{array}{l}\text { Percent change with account } \\
\text { (relative to scheduled benefit) } \\
\text { at } 2 \text { percent rate for liability } \\
\text { accounts }\end{array}$ & $-12 \%$ & $-23 \%$ & $-27 \%$ \\
\hline $\begin{array}{l}\text { Percent change with account } \\
\text { (relative to scheduled benefit) } \\
\text { at } 3 \text { percent rate for liability } \\
\text { accounts }\end{array}$ & $-22 \%$ & $-32 \%$ & $-35 \%$ \\
\hline $\begin{array}{l}\text { Subsidy as percent of } \\
\text { scheduled benefit }\end{array}$ & $9 \%$ & $10 \%$ & $8 \%$ \\
\hline
\end{tabular}

\section{Model 3}

\begin{tabular}{|l|c|c|c|}
\hline & $\begin{array}{c}\text { Low earner } \\
(\$ 15,875 \text { in 2002) }\end{array}$ & $\begin{array}{c}\text { Medium earner } \\
(\$ 35,277 \text { in 2002) }\end{array}$ & $\begin{array}{c}\text { High earner } \\
(\$ 56,443 \text { in 2002) }\end{array}$ \\
\hline $\begin{array}{l}\text { Percent change without } \\
\text { account (relative to scheduled } \\
\text { benefit) }\end{array}$ & $-32 \%$ & $-40 \%$ & $-42 \%$ \\
\hline $\begin{array}{l}\text { Percent change with account } \\
\text { (relative to scheduled benefit) } \\
\text { at 2.5 percent rate for liability } \\
\text { accounts }\end{array}$ & $-9 \%$ & $-10 \%$ & $-9 \%$ \\
\hline $\begin{array}{l}\text { Percent change with account } \\
\text { (relative to scheduled benefit) } \\
\text { at 3 percent rate for liability } \\
\text { accounts }\end{array}$ & $-13 \%$ & $-14 \%$ & $-12 \%$ \\
\hline & & & \\
\hline $\begin{array}{l}\text { Subsidy as percent of } \\
\text { scheduled benefit }\end{array}$ & $3 \%$ & $4 \%$ & $4 \%$ \\
\hline
\end{tabular}

Note: Based on intermediate assumptions from 2001 Trustees Report and assumed net return (after administrative costs) of 4.6 percent per year. Return assumption reflects 3.0 percent ultimate real yield on Treasury securities; 6.5 percent return on equity; 3.5 percent return on corporate bonds; and 0.3 percent administrative costs. The portfolio is assumed to be 50 percent bonds and 50 percent equity. The bond component comprises 60 percent corporate bonds and 40 percent Treasury bonds. Annuitization assumes actuarially fair, CPI-indexed joint-and-two-thirdssurvivor annuities and the mortality projections from the 2001 Trustees Report.

Source: Memorandum from the Office of the Chief Actuary, pages 75-76, and authors' calculations. 
Table 29: Expected combined benefit levels for each member of medium-earning twoearner couples claiming at age 65 in 2052 under different return assumptions

Model 2

\begin{tabular}{|l|c|c|c|}
\hline $\begin{array}{l}\text { Monthly amount, in 2001 } \\
\text { dollars }\end{array}$ & Low yield & $50-50$ equity-bond & High yield \\
\hline $\begin{array}{l}\text { Scheduled benefit } \\
\text { - Benefit change for all }\end{array}$ & $\$ 1,628$ & $\$ 1,628$ & $\$ 1,628$ \\
\hline $\begin{array}{l}+ \text { Annuity from individual } \\
\text { account }\end{array}$ & $\$ 529$ & $-\$ 529$ & $-\$ 529$ \\
\hline - Offset from liability account & $-\$ 393$ & $\$ 819$ & $\$ 889$ \\
\hline = Total expected benefit & $\$ 1,204$ & $-\$ 393$ & $-\$ 393$ \\
\hline $\begin{array}{l}\text { Percent change relative to } \\
\text { scheduled benefit }\end{array}$ & $-26 \%$ & $-6 \%$ & $\$ 1,595$ \\
\hline
\end{tabular}

\section{Model 3}

\begin{tabular}{|l|c|c|c|}
\hline $\begin{array}{l}\text { Monthly amount, in 2001 } \\
\text { dollars }\end{array}$ & Low yield & $50-50$ equity-bond & High yield \\
\hline Scheduled benefit & $\$ 1,628$ & $\$ 1,628$ & $\$ 1,628$ \\
\hline - Benefit change for all & $-\$ 353$ & $-\$ 353$ & $-\$ 353$ \\
\hline $\begin{array}{l}\text { + Annuity from individual } \\
\text { account (including 1 percent } \\
\text { additional contribution) }\end{array}$ & $\$ 574$ & $\$ 930$ & $\$ 1,006$ \\
\hline - Offset from liability account & $-\$ 383$ & $-\$ 383$ & $-\$ 383$ \\
\hline = Total expected benefit & $\$ 1,465$ & $\$ 1,821$ & $\$ 1,897$ \\
\hline $\begin{array}{l}\text { Percent change relative to } \\
\text { Scheduled benefit }\end{array}$ & $-10 \%$ & $+12 \%$ & $+17 \%$ \\
\hline
\end{tabular}

Notes: Based on intermediate assumptions from 2001 Trustees Report

50-50 equity-bond yields an assumed net return (after administrative costs) of 4.6 percent per year. Return assumption reflects 3.0 percent ultimate real yield on Treasury securities; 6.5 percent return on equity; 3.5 percent return on corporate bonds; and 0.3 percent administrative costs. The portfolio is assumed to be 50 percent bonds and 50 percent equity. The bond component comprises 60 percent corporate bonds and 40 percent Treasury bonds. Annuitization assumes actuarially fair, CPI-indexed joint-and-two-thirds-survivor annuities and the mortality projections from the 2001 Trustees Report.

Low yield reflects the Treasury bond yield for all assets. In addition, annuitization interest rate is reduced by 30 basis points relative to Treasury bond yield.

High yield assumes a 7.1 percent yield on equities (or investing 60 percent of portfolio in equities at 6.5 percent yield).

Source: Memorandum from the Office of the Chief Actuary, pages 75-76, and authors' calculations. 
Table 30: Expected combined benefit levels for each member of medium-earning twoearner couples claiming at age 65 in 2075 under different return assumptions

Model 2

\begin{tabular}{|l|c|c|c|}
\hline $\begin{array}{l}\text { Monthly amount, in 2001 } \\
\text { dollars }\end{array}$ & Low yield & $50-50$ equity-bond & High yield \\
\hline $\begin{array}{l}\text { Scheduled benefit } \\
\text { - Benefit change for all }\end{array}$ & $\$ 2,032$ & $\$ 2,032$ & $\$ 2,032$ \\
\hline $\begin{array}{l}\text { + Annuity from individual } \\
\text { account }\end{array}$ & $\$ 600$ & $-\$ 933$ & $-\$ 933$ \\
\hline - Offset from liability account & $-\$ 473$ & $\$ 989$ & $\$ 1,073$ \\
\hline$=$ Total expected benefit & $\$ 1,227$ & $\$ 473$ & $-\$ 473$ \\
\hline $\begin{array}{l}\text { Percent change relative to } \\
\text { scheduled benefit }\end{array}$ & $-40 \%$ & $-21 \%$ & $\$ 1,700$ \\
\hline
\end{tabular}

\section{Model 3}

\begin{tabular}{|l|c|c|c|}
\hline $\begin{array}{l}\text { Monthly amount, in 2001 } \\
\text { dollars }\end{array}$ & Low yield & $50-50$ equity-bond & High yield \\
\hline Scheduled benefit & $\$ 2,032$ & $\$ 2,032$ & $\$ 2,032$ \\
\hline - Benefit change for all & $-\$ 607$ & $-\$ 607$ & $-\$ 607$ \\
\hline $\begin{array}{l}\text { + Annuity from individual } \\
\text { account (including 1 percent } \\
\text { additional contribution) }\end{array}$ & $\$ 692$ & $\$ 1,123$ & $\$ 1,215$ \\
\hline - Offset from liability account & $-\$ 462$ & $-\$ 462$ & $-\$ 462$ \\
\hline - Total expected benefit & $\$ 1,655$ & $\$ 2,086$ & $\$ 2,178$ \\
\hline $\begin{array}{l}\text { Percent change relative to } \\
\text { Scheduled benefit }\end{array}$ & $-19 \%$ & $+3 \%$ & $+7 \%$ \\
\hline
\end{tabular}

Notes: Based on intermediate assumptions from 2001 Trustees Report

50-50 equity-bond yields an assumed net return (after administrative costs) of 4.6 percent per year. Return assumption reflects 3.0 percent ultimate real yield on Treasury securities; 6.5 percent return on equity; 3.5 percent return on corporate bonds; and 0.3 percent administrative costs. The portfolio is assumed to be 50 percent bonds and 50 percent equity. The bond component comprises 60 percent corporate bonds and 40 percent Treasury bonds. Annuitization assumes actuarially fair, CPI-indexed joint-and-two-thirds-survivor annuities and the mortality projections from the 2001 Trustees Report.

Low yield reflects the Treasury bond yield for all assets. In addition, annuitization interest rate is reduced by 30 basis points relative to Treasury bond yield.

High yield assumes a 7.1 percent yield on equities (or investing 60 percent of portfolio in equities at 6.5 percent yield).

Source: Memorandum from the Office of the Chief Actuary, pages 75-76, and authors' calculations. 
Table 31: Expected combined benefit levels for scaled medium-earning couples claiming benefits at age 65 in different years

Model 2

\begin{tabular}{|l|c|c|c|c|}
\hline \multicolumn{5}{|c|}{$\begin{array}{c}\text { Level of Benefit Assuming CPI Annuitization of Entire Individual Account } \\
\text { Relative to Paying Scheduled Benefits in Current Law }\end{array}$} \\
\hline $\begin{array}{l}\text { Year reaching } \\
\text { age 65 }\end{array}$ & \multicolumn{2}{|c|}{ Two-earner couple } & \multicolumn{2}{c|}{ One-earner couple } \\
\hline & $\begin{array}{c}\text { Not adjusted } \\
\text { for risk }\end{array}$ & $\begin{array}{c}\text { Adjusted for } \\
\text { risk* }\end{array}$ & $\begin{array}{c}\text { Not adjusted for } \\
\text { risk }\end{array}$ & $\begin{array}{c}\text { Adjusted for } \\
\text { risk* }\end{array}$ \\
\hline 2012 & 100.0 & 99.5 & 99.7 & 99.4 \\
\hline 2022 & 93.9 & 91.5 & 92.7 & 91.0 \\
\hline 2032 & 91.7 & 84.8 & 88.5 & 83.8 \\
\hline 2042 & 94.1 & 79.5 & 87.7 & 77.8 \\
\hline 2052 & 93.7 & 73.9 & 85.2 & 71.9 \\
\hline 2075 & 79.5 & 60.4 & 71.3 & 58.3 \\
\hline
\end{tabular}

Source: Memorandum from the Office of the Chief Actuary, pages 75 and 78 .

* As measured by the low-yield calculations undertaken by the actuaries

\section{Model 3}

\begin{tabular}{|l|c|c|c|c|}
\hline \multicolumn{5}{|c|}{$\begin{array}{c}\text { Level of Benefit Assuming CPI Annuitization of Entire Individual Account } \\
\text { Percent of Scheduled Benefits in Current Law }\end{array}$} \\
\hline $\begin{array}{l}\text { Year reaching } \\
\text { age 65 }\end{array}$ & \multicolumn{2}{|c|}{ Two-earner couple } & \multicolumn{2}{c|}{ One-earner couple } \\
\hline & $\begin{array}{c}\text { Not adjusted } \\
\text { for risk }\end{array}$ & $\begin{array}{c}\text { Adjusted for } \\
\text { risk* }\end{array}$ & $\begin{array}{c}\text { Not adjusted for } \\
\text { risk }\end{array}$ & $\begin{array}{c}\text { Adjusted for } \\
\text { risk* }\end{array}$ \\
\hline 2012 & 100.9 & 100.4 & 100.3 & 100.0 \\
\hline 2022 & 99.1 & 95.9 & 96.8 & 94.6 \\
\hline 2032 & 102.8 & 93.8 & 97.5 & 91.5 \\
\hline 2042 & 110.3 & 92.8 & 101.2 & 89.4 \\
\hline 2052 & 111.9 & 90.0 & 101.0 & 86.2 \\
\hline 2075 & 102.7 & 81.5 & 92.1 & 77.8 \\
\hline
\end{tabular}

Source: Memorandum from the Office of the Chief Actuary, pages 76 and 79.

* As measured by the low-yield calculations undertaken by the actuaries 
Table 32: Assets in individual accounts under Models 2 and 3 assuming all eligible workers contribute to individual accounts

\begin{tabular}{|c|c|c|}
\hline As \% of GDP & Model 2 & Model 3 \\
\hline 2010 & $5.2 \%$ & $6.5 \%$ \\
\hline 2020 & $16.0 \%$ & $19.8 \%$ \\
\hline 2030 & $28.2 \%$ & $35.0 \%$ \\
\hline 2040 & $39.5 \%$ & $49.0 \%$ \\
\hline 2050 & $47.9 \%$ & $59.4 \%$ \\
\hline 2060 & $52.1 \%$ & $64.6 \%$ \\
\hline 2070 & $53.1 \%$ & $65.9 \%$ \\
\hline 2075 & $52.9 \%$ & $65.6 \%$ \\
\hline
\end{tabular}

Source: Memorandum from the Office of the Chief Actuary; President's Commission to Strengthen Social Security, and authors' calculations

Table 33: Benefit difference from scheduled benefits under Model 2 and alternative plans that achieve 75-year balance with equal general revenue transfers

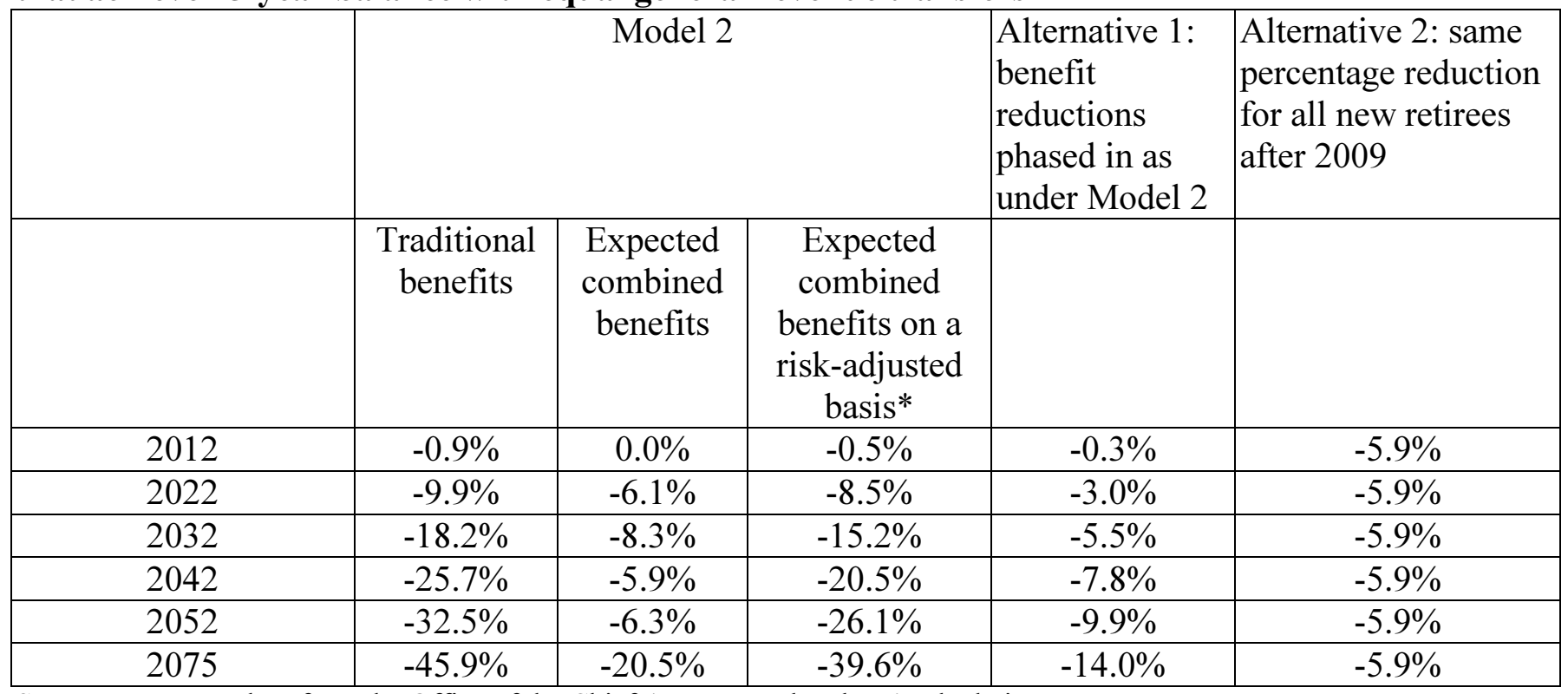

Source: Memorandum from the Office of the Chief Actuary, and authors' calculations

* As measured by the "low yield" calculations undertaken by the actuaries 